\title{
ON THE GERMAN MONETARY TRANSMISSION MECHANISM: INTEREST RATE AND CREDIT CHANNELS FOR INVESTMENT SPENDING
}

\author{
ROBERT S. CHIRINKO \\ ULF VON KALCKREUTH
}

CESiFo Working PAPER No. 838

CATEGORY 6: MONETARY PoliCy AND InTERnATIONAL FinANCE

JANUARY 2003

\footnotetext{
An electronic version of the paper may be downloaded

- from the SSRN website: www.SSRN.com

- from the CESifo website: www.CESifo.de
} 


\title{
ON THE GERMAN MONETARY TRANSMISSION MECHANISM: INTEREST RATE AND CREDIT CHANNELS FOR INVESTMENT SPENDING
}

\begin{abstract}
The transmission channels through which monetary policy affects business investment remain opaque. This paper examines the importance of the interest rate and credit channels on business fixed investment in Germany. We have at our disposal three uniquely rich datasets -- a panel of financial statement data for 6,408 firms (44,345 datapoints) supplemented with user costs of capital and confidential measures of creditworthiness. We uncover a statistically significant interest rate channel. Its economic significance can be sizeable, but depends on auxiliary assumptions. Sorting firms with our direct measure of creditworthiness, we find that credit constraints are important for a subset of firms. Sortings by firm size or dividend payout ratios shed some light on continuing debates in the literature.
\end{abstract}

JEL Classification: E5, E22.

Robert S. Chirinko

Department of Economics

Emory University

1602 Mizell Drive

Atlanta, Georgia

USA

rchirin@emory.edu
Ulf von Kalckreuth

Deutsche Bundesbank

Economic Research Centre

P.O.Box 100602

Wilhelm-Epstein Strasse 14

60006 Frankfurt

Germany

ulf.von-kalckreuth@bundesbank.de 


\title{
On The German Monetary Transmission Mechanism: Interest Rate And Credit Channels For Investment Spending
}

\begin{abstract}
And I'm not saying that there is a black box, or anything of that nature, but the complexity of our economy is such, and the way liquidity flows through the system is such that you essentially get very complex differences in the way monetary policy plays out, but at the end of the day, it does seem to be effective.
\end{abstract}

Alan Greenspan (2001)

\section{Introduction}

Since the publication of the landmark Monetary History by Friedman and Schwartz (1963), there has been increasing acceptance that monetary policy matters for short-run fluctuations. ${ }^{1}$ Nonetheless, the precise channels through which monetary policy affects economic activity remain opaque. This paper sheds some light on the black box of monetary transmission by exploiting three particularly rich datasets containing detailed panel data on creditworthiness, user costs, and financial statements for a large number of German firms.

A recent symposium (Mishkin, 1995) highlights both the consensus that money matters and the continuing disagreements over the transmission channels through which money affects aggregate demand. The traditional interest rate channel links monetary policy to real activity directly by changes in interest rates. Spending elasticities are a key element for the empirical relevance of this channel. While debatable, there is substantial evidence that these elasticities are too low to account for the observed potency of monetary policy, and hence questions arise concerning the quantitative importance of the interest rate channel of monetary policy. ${ }^{2}$

These low price elasticities have partly motivated research on a second transmission mechanism to explain money's powerful impact on economic activity. ${ }^{3}$ The credit channel holds that variations in the price and availability of credit are also elements in monetary transmission. Monitoring costs affect the price and

\footnotetext{
1 Among many studies, see Romer and Romer (1989), Bernanke and Blinder (1992), and Christiano, Eichenbaum, and Evans (1996) for evidence for the United States, and the surveys by Blanchard (1990) and Christiano, Eichenbaum, and Evans (1999).

${ }^{2}$ For business fixed investment in the United States, see the surveys by Chirinko (1993a, 1993b), who concludes that the response of investment to its user cost is low. Contrasting (high elasticity) interpretations can be found in Taylor (1995) and Hassett and Hubbard (1997).

${ }^{3}$ Low price elasticities have also prompted some researchers to examine the impact of irreversible capital and uncertainty in order to understand investment behavior (Dixit and Pindyck, 1994; Caballero, 1999).
} 
availability of credit. Asymmetric information results in moral hazard and adverse selection problems that create a wedge between the costs of internal and external finance. Contractionary monetary policy increases the wedge. Consequently, the effective cost of external finance is raised for those firms whose credit rating is suspect, and investment spending is reduced.

To obtain a better understanding of monetary policy in industrialized countries, this paper examines the strength of the interest rate and credit channels on business fixed investment, which is a large and highly volatile component of aggregate demand. We begin in Section II by describing the three unique datasets for German firms at our disposal. First, as part of its rediscount lending operation (described more fully in Section II.C), the Bundesbank routinely determined overall creditworthiness through a detailed discriminant analysis. ${ }^{4}$ These confidential credit ratings are a precise indicator of those firms facing a substantial external finance wedge. Our direct creditworthiness measure allows for more accurate inferences than is possible with the indirect measures used previously in the literature. Second, we compute user costs of capital (which include the interest rate) along the lines presented in King and Fullerton (1984), adapting important prior work by Harhoff and Ramb (2001) and Ramb (2003) for the purposes of this study. The user cost variable is key to evaluating the interest rate channel of monetary policy. Third, in discharging its credit evaluation obligation, the Bundesbank also collects a vast amount of detailed financial statement data. After accounting for lags, outliers, and missing observations, we have 44,345 datapoints for 6,408 firms for the period 1988-1997. In combination, these three datasets provide a unique opportunity to analyze the interest rate and credit channels of monetary policy.

Model specification issues are considered in Section III. We begin with a discussion of the econometric equation. Investment models can be set into one of two broad classes depending on how explicitly the econometric model follows from a formal optimization problem. The explicit and implicit modeling strategies are evaluated. Given the questions we wish to address and the empirical performance of many explicit models, we adopt an implicit modeling strategy. Our estimating equation is based on the neoclassical theory of capital accumulation (beginning with Jorgenson, 1963), and is an Autoregressive Distributed Lag (ADL) model relating the investment/capital ratio to current and lagged values of a price variable (the growth rate in user cost), a quantity variable (the growth rate in sales), and a financing variable (cash flow scaled by the capital stock), as well as lags of the dependent variable.

\footnotetext{
${ }^{4}$ Since the implementation of the Monetary Union on January 1, 1999, the Bundesbank continues to assess creditworthiness in the course of the Eurosystem monetary policy operations, but it no longer rediscounts trade bills.
} 
Section IV contains our baseline empirical results. We evaluate three different GMM estimation strategies for our dynamic panel model and various lag lengths. The specification tests favor a model with three lags and fixed effects removed by first differencing.

Sections V and VI evaluate the interest rate and credit channels, respectively, for business fixed investment. A statistically significant interest rate channel is identified in Section V. Economic significance is evaluated by investment's responsiveness to variations in interest rates. A 100 basis point decrease in the real long-term rate for two years would increase investment by $7.55 \%$. The power of the interest rate channel, however, depends on the relation between short-term monetary policy instruments and long-term real capital market rates.

In Section VI, the credit channel is evaluated with two differential sensitivity tests, one with respect to cash flow (used frequently in previous studies) and a new test that focuses on user cost coefficients. We use our unique measure of creditworthiness to sort firms by their susceptibility to finance constraints. Financially constrained firms exhibit increased sensitivity to cash flow and decreased sensitivity to price incentives (embedded in the user cost) relative to unconstrained firms. Both results suggest the importance of credit constraints for a subset of firms. Other sortings are performed for firm size and the dividend payout ratio. When the creditworthiness measure is included as an additional regressor, it proves significant.

Section VII draws conclusions for monetary transmission in Germany, and suggests the direction of future work.

\section{A. Creditworthiness Ratio (CWR)}

\section{Datasets}

A unique element in this study is the set of creditworthiness ratios (Gesamtkennzahl, CWR's) generated by the Bundesbank in performing its rediscounting and lending operations. Bills of exchange are issued by nonfinancial firms, and were frequently presented to the Bundesbank by credit institutions (cf. fn. 4). When a bill was presented for discounting, the creditworthiness of the issuing firm and all other firms that have held this bill needed to be determined. In the case of default, liability for payment of the bill fell on any firm that had held the bill. By law, the Bundesbank could only accept bills backed by three parties known to be creditworthy.

The Bundesbank evaluates firms by undertaking a massive effort at collecting financial statement data (discussed in Section II.C) and computing CWR's using discriminant analysis. ${ }^{5}$ The two underlying populations are solvent and insolvent

\footnotetext{
${ }^{5}$ See Deutsche Bundesbank (1999) for further details about the construction of the CWR's and the credit evaluation process.
} 
firms, where insolvency is indicated by a legal application for bankruptcy. The sample is constructed by first identifying the relatively scarce insolvent firms, and then adding a solvent firm from the same sector. To enhance the statistical properties of the discriminant function, the sample contains an equal number of solvent and insolvent firms. The following information is used to compute the discriminant function: 1) equity/pension provision ratio (adjusted equity capital and pension provisions as a percentage of total capital employed); 2) return on total capital employed (profit before income taxes and before interest payments as a percentage of total capital employed); 3) return on equity (profit before income taxes as a percentage of adjusted equity income); 4) capital recovery rate (net receipts as a percentage of capital invested); 5) net interest payment ratio (net interest as a percentage of turnover); 6) accounting practice (which affects available valuation methods). The weights assigned to these categories are confidential. These ratios are examined by the Bundesbank's Department of Credit, Foreign Exchange, and Financial Markets for outliers. The original CWR's range between -99.9 and 99.9, and have been transformed for this study to vary between 0 and 1 .

The discriminant analysis determines two critical values of the CWR that classifies firms into one of three categories: high degree of creditworthiness (Good), low degree of creditworthiness (Endangered), or indeterminate. The proportion of distressed firms in the data used in the discriminant analysis appears representative, and compares favorably to the percentage of failed firms in the overall economy (Deutsche Bundesbank, 1998; Stoess, 2001).

B. User Cost (UC)

The user cost of capital (UC) is the variable through which the interest rate channel of monetary policy operates. In very simple terms, the user cost is comprised of three components,

$$
\mathrm{UC}=\mathrm{R} * \mathrm{P} * \mathrm{~T},
$$

where R, P, and T represent rental, price, and tax terms, respectively. The rental term contains two components, the opportunity cost of funds measured by the real long-term interest rate $(\mathrm{r}=\mathrm{i}-\pi$, the nominal discount rate (i) less the expected rate of inflation $(\pi)$ in the price of investment goods) and the economic rate of depreciation $(\delta)$. The $\mathrm{P}$ term is the price of investment goods relative to the price of output. Two key taxes entering $\mathrm{T}$ are the rate of income taxation (reflecting both federal and Laender rates, as well as the "solidarity surcharge") and the present value of the stream of current and future tax depreciation deductions.

Equation (1) summarizes the price incentives faced by a profit-maximizing firm (conditioned on the level of output) when evaluating the acquisition of the marginal unit of capital. However, the user cost variable used in this study is much more complicated. These important details are discussed in Appendix A. 


\section{Financial Statements (UBS)}

The Bundesbank's financial statement database (Unternehmensbilanzstatistik, UBS) constitutes the largest source of accounting data for nonfinancial firms in Germany. ${ }^{6}$ About 70,000 annual accounts were collected per year on a strictly confidential basis by the Bundesbank's branch offices. These data were initially subjected to a computer check for logical errors and missing data. Approximately 15,000 accounts had to be excluded because they were incomplete, represented consolidated accounts, or were for firms in sectors (e.g., agriculture) for which no meaningful results could be generated owing to the small amount of available data. Additional checks and corrections for errors were undertaken in the Statistical Department at the Bundesbank's Central Office in Frankfurt before finalizing the UBS database.

The dataset used in estimation is smaller for several reasons. We use data only for firms located in the manufacturing sector of West Germany to avoid any issues of comparability between the western and eastern sections of the country. Sole proprietorships and private partnerships are excluded because their tax treatment depends on personal characteristics that are very difficult to quantify and, since they do not have a meaningful dividend decision, the split sample analysis in Section VI.C would not be feasible. State dominated corporations are also excluded. The dataset is further reduced by first-differencing, missing values, data cleaning, variable construction involving lags, and outlier control. ${ }^{7}$ The data extend from 1988 to $1997 .{ }^{8}$ We thus have available for our preferred econometric specification containing three lags (discussed in Section IV) 44,345 datapoints for 6,408 firms. For 1996, these data represent $42 \%$ of the total turnover of the West German manufacturing sector and $61 \%$ of the total turnover of incorporated firms in all German manufacturing.

\section{Summary Statistics}

Table 1 contains summary statistics for the variables that will enter the econometric specification; variable definitions are displayed in the table note. Subsamples to be used in subsequent estimation are defined by CWR, firm size as measured by the average number of employees, and the dividend payout ratio. The

\footnotetext{
${ }^{6}$ This discussion draws on the Deutsche Bundesbank (1998) and Stoess (2001), which contain more detailed descriptions of the UBS data. The UBS has been utilized by Harhoff and Ramb (2001) in a user cost study and von Kalckreuth (2000) in an uncertainty study.

${ }^{7}$ We control for outliers by discarding the upper and lower $1 \%$ tails of sales growth, cash flow divided by the capital stock, and the CWR, and the upper $2 \%$ tail of the investment capital ratio.

${ }^{8}$ The beginning year of 1988 is chosen because the definitions of many important financial statement variables were changed in 1986 by the directive harmonizing financial statements in the European Union. For many firms, the changes were not instituted in 1987, and the amount of data available in the UBS is unacceptably low in that year.
} 
means of the variables across the sub-samples defined by the three sorting variables are presented in Table 2. A noteworthy feature of the UBS dataset is

Table 1: Summary Statistics for the Full Sample

\begin{tabular}{|c|c|c|c|c|c|c|c|}
\hline \multicolumn{1}{|c|}{$(\mathbf{1})$} & $\mathbf{( 2 )}$ & $\mathbf{( 3 )}$ & $\mathbf{( 5 )}$ & $\mathbf{( 6 )}$ & $\mathbf{( 7 )}$ \\
\hline $\mathbf{I}_{\mathbf{t}} / \mathbf{K}_{\mathbf{t}-\mathbf{1}}$ & 0.1813 & 0.220 & 0 & 0.0585 & 0.1161 & 0.2157 & 2.2138 \\
\hline$\Delta \mathbf{l o g U C}_{\mathbf{t}}$ & 0.0222 & 0.0717 & -0.3478 & -0.0178 & 0.0094 & 0.0644 & 0.4991 \\
\hline $\mathbf{U C}_{\mathbf{t}}$ & 0.1587 & 0.0183 & 0.0857 & 0.1457 & 0.1572 & 0.1697 & 0.2812 \\
\hline$\Delta \mathbf{l o g S}_{\mathbf{t}}$ & 0.0206 & 0.1597 & -0.5959 & -0.0654 & 0.0214 & 0.1068 & 0.8308 \\
\hline $\mathbf{S}_{\mathbf{t}}$ & 173.15 & 1455.12 & 0.27 & 9.94 & 26.13 & 71.25 & $65,900.0$ \\
\hline $\mathbf{C F}_{\mathbf{t}} / \mathbf{K}_{\mathbf{t}-\mathbf{1}}$ & 0.2843 & 0.4941 & -1.9143 & 0.1091 & 0.1887 & 0.3308 & 9.2678 \\
\hline$\Delta \mathbf{C W R}_{\mathbf{t}}$ & 0.0004 & 0.0427 & -0.3515 & -0.0210 & 0.0050 & 0.0220 & 0.4905 \\
\hline $\mathbf{C W R}_{\mathbf{t}}$ & 0.5736 & 0.0618 & 0.3655 & 0.5355 & 0.5735 & 0.6150 & 0.7390 \\
\hline
\end{tabular}

Notes To Table 1:

The sample contains 44,345 datapoints for 6408 firms for 1988-1997, and is the sample used for the benchmark ADL(3) model. $\mathrm{I}_{t} / \mathrm{K}_{\mathrm{t}-1}$ is the investment/capital ratio; $\mathrm{UC}_{\mathrm{t}}$ is the user cost of capital; $\mathrm{S}_{\mathrm{t}}$ is real sales in millions of Deutschmarks; $\mathrm{CF}_{\mathrm{t}} / \mathrm{K}_{\mathrm{t}-1}$ is the cash flow/capital ratio; $\mathrm{CWR}_{\mathrm{t}}$ is the creditworthiness ratio; $\Delta$ is the first-difference operator. See Section II and Appendix A for more details about the variables. 
Table 2: Means For Sub-Samples

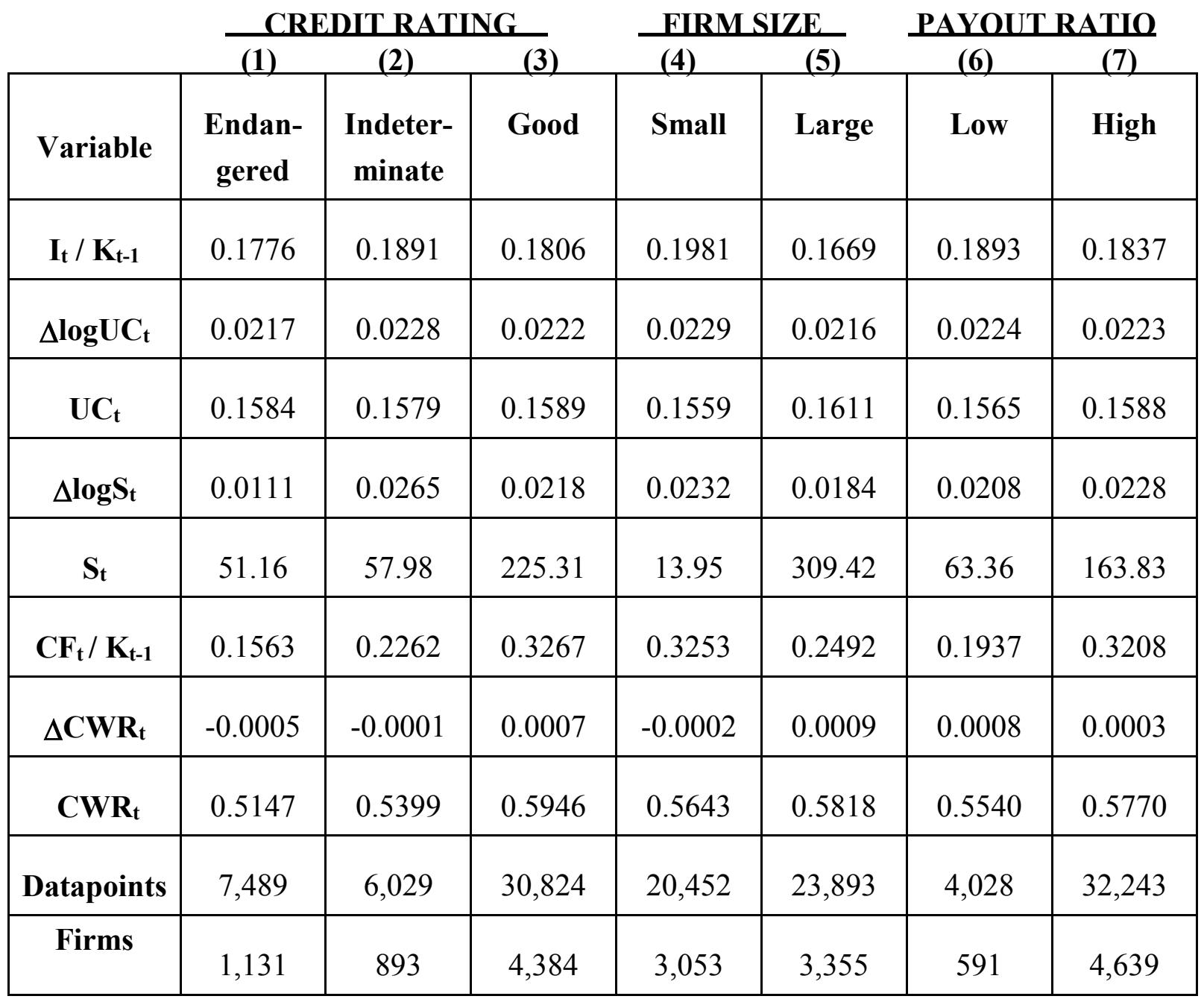

Notes To Table 2:

See the note to Table 1 for variable definitions. The sub-samples presented in columns 1-3 are defined by CWR : Endangered [Good] are those datapoints below [above] the lower [higher] critical value of CWR; Indeterminate are those datapoints between the two critical values. The subsamples presented in columns 4-5 are sorted by the number of employees: Small are those datapoints for firms with less than 100 employees; Large is the complementary class. The subsamples presented in columns 6-7 are sorted by the dividend payout ratio: Low are those datapoints for firms that did not pay a dividend; High is the complementary class. The number of datapoints in the sub-samples is less than that for the full sample because some datapoints could not be classified. 
the extensive coverage of small firms. Table 3 presents the size distribution of the datapoints by mean employment, and documents the remarkable representation of small firms in the UBS dataset. Nearly one-half of the observations in the full sample are for firms with 100 employees or fewer.

\section{Table 3: Size Distribution Of Firms And Datapoints Measured By Mean Employment}

\begin{tabular}{|c|c|c|c|c|c|c|}
\hline & $\mathbf{n} \leq \mathbf{2 0}$ & $\mathbf{2 0}<\mathbf{n} \leq \mathbf{1 0 0}$ & $\mathbf{1 0 0}<\mathbf{n} \leq \mathbf{2 5 0}$ & $\mathbf{2 5 0}<\mathbf{n}<\mathbf{5 0 0}$ & $\mathbf{n}>\mathbf{5 0 0}$ & Sum \\
\hline Firms & 616 & 2,437 & 1,626 & 828 & 901 & 6,408 \\
\hline & $9.61 \%$ & $38.03 \%$ & $25.37 \%$ & $12.92 \%$ & $14.06 \%$ & $100 \%$ \\
\hline Datapoints & 3,989 & 16,463 & 11,372 & 5,936 & 6,589 & 44,345 \\
\hline & $9.00 \%$ & $37.12 \%$ & $25.64 \%$ & $13.39 \%$ & $14.85 \%$ & $100 \%$ \\
\hline
\end{tabular}

Notes To Table 3:

For the full sample, the mean and median number of employees (n) is 405 and 119, respectively. The sample contains 44,345 datapoints for 6,408 firms for 1988-1997, and is the sample used for the benchmark ADL(3) model. In 1996, these firms have 2,593,100 employees, representing about $45 \%$ of total employment in the West German manufacturing sector.

\section{Model Specification}

The numerous models appearing in the investment literature can be divided into two broad categories depending on whether dynamic elements are treated explicitly or implicitly. ${ }^{9}$ Models are included in the former category if dynamic elements appear explicitly in the optimization problem and if the estimated coefficients are linked explicitly to the underlying technology and expectation parameters. The implicit category contains those investment models that do not meet these criteria. These different approaches are reviewed below in light of our goal of assessing quantitatively the monetary transmission mechanism.

The most popular explicit models can be derived from a common optimization problem. If frictions are modeled as convex adjustment costs, then the first-order conditions for intertemporal profit maximization imply a decision rule for investment spending in which the investment/capital ratio is a function of the shadow price of capital, defined as the discounted sum of current and future returns

\footnotetext{
${ }^{9}$ This section draws on Chirinko (1993a, 1993b), which contains an extensive list of references.
} 
from the marginal unit of capital. The key problem facing the applied econometrician is that this shadow price is not observed. Investment models based on convex adjustment cost frictions -- the Brainard-Tobin's Q, Euler Equation, and Direct Forecasting -- differ only in how the applied econometrician solves this unobservability problem. ${ }^{10}$

Explicit models have the notable advantages of being based on a choicetheoretic framework and having coefficients in the econometric equation that can be identified with technology and expectation parameters. However, their empirical performance has been disappointing, their parameter estimates appear fragile in many applications, and they do not provide a framework for assessing both the interest rate and credit channels for investment spending. Consequently, given the current state of development of explicit models, our analysis can best be carried out with an implicit model.

There is a wide variety of implicit models. The specification used in this paper defines a desired capital stock in terms of user cost and sales variables having separate elasticities. This demand for the stock of capital is translated into a demand for the flow of investment by relating the percentage change in capital (or the investment/capital ratio less depreciation, $\mathrm{I} / \mathrm{K}-\delta$ ) to the current and lagged percentage changes in the user cost (UC) and sales (S). To allow for a general pattern of dynamic responses, lagged dependent variables are included. We also enter current and lagged values of a financing variable, the ratio of cash flow to the capital stock $(\mathrm{CF} / \mathrm{K})$, to capture the effects of financing constraints. These considerations lead to the estimating equation as the following autoregressive distributed lag $(\mathrm{ADL}(\mathrm{H}))$ model of lag length $\mathrm{H}$ :

$$
\begin{aligned}
\mathrm{I}_{\mathrm{i}, \mathrm{t}} / \mathrm{K}_{\mathrm{i}, \mathrm{t}-\mathrm{l}}=\zeta_{\mathrm{i}} & -\sum_{\mathrm{h}=0}^{\mathrm{H}} \alpha_{\mathrm{h}} \Delta \log \mathrm{UC}_{\mathrm{i}, \mathrm{t}-\mathrm{h}} \\
& +\sum_{\mathrm{h}=0}^{\mathrm{H}} \beta_{\mathrm{h}} \Delta \log \mathrm{S}_{\mathrm{i}, \mathrm{t}-\mathrm{h}} \\
& \mathrm{H} \\
+\sum_{\mathrm{h}=0}^{\mathrm{H}} \gamma_{\mathrm{h}}\left(\mathrm{CF}_{\mathrm{i}, \mathrm{t}-\mathrm{h}} / \mathrm{K}_{\mathrm{i}, \mathrm{t}-1-\mathrm{h}}\right) & +\sum_{\mathrm{h}=1}^{\mathrm{H}} \lambda_{\mathrm{h}}\left(\mathrm{I}_{\mathrm{i}, \mathrm{t}-\mathrm{h}} / \mathrm{K}_{\mathrm{i}, \mathrm{t}-1-\mathrm{h}}\right)+\tau_{\mathrm{t}}+\mathrm{e}_{\mathrm{i}, \mathrm{t}},
\end{aligned}
$$

where the $\alpha$ 's, $\beta$ 's, $\gamma$ 's, and the $\lambda$ 's are estimated coefficients, $\tau_{\mathrm{t}}$ is a series of time dummies that capture aggregate shocks, $e_{i, t}$ is a stochastic error term, $i$ indexes firms,

\footnotetext{
${ }^{10}$ Some other frictions lead to only modest changes in the decision rule. The model of irreversibility and uncertainty of Abel and Eberly (1994) generates a specification where the Brainard-Tobin's Q appears as a polynomial. Time-to-build and delivery lags alter timing relations in the benchmark explicit model (Barnett and Sakellaris, 1998).
} 
and t indexes time. ${ }^{11}$ The $\zeta_{\mathrm{i}}$ coefficient reflects the firm's mix of capital assets, is proportional to the depreciation rate $\left(\delta_{\mathrm{i}}\right)$, and is firm specific. More generally, this firm-specific constant term captures all firm-specific effects. The other coefficients do not vary across firms. A derivation of (2) is provided in Appendix B.

Equation (2) has three important advantages for assessing the monetary transmission mechanism. First, a similar specification has been used frequently, and has performed well empirically. ${ }^{12}$ Second, a user cost variable appears in the specification, and provides a direct means for considering the interest rate channel of monetary policy. The user cost varies both through time and across firms, and thus panel data can be very useful in estimating user cost coefficients. Third, equation (2) allows us to assess the importance of the credit channel by examining the coefficients on cash flow. The major concern with implicit models is the Lucas Critique. While undoubtedly correct theoretically, the Lucas Critique does not appear to be quantitatively important. ${ }^{13}$

\footnotetext{
${ }^{11}$ Note that the H's for the individual distributed lags and lagged dependent variable will differ in the trimmed results to be presented in Tables 5-9.

${ }^{12}$ This model was developed over several years in spirited exchanges. Among other studies, see Jorgenson (1963), Jorgenson and Stephenson (1967, 1969), Hall and Jorgenson (1967, 1969), Coen (1969), and Eisner and Nadiri (1968, 1970). Chirinko, Fazzari, and Meyer (1999), Harhoff and Ramb (2001), and Bond, Elston, Mairesse, and Mulkay (2001) use variants of this model recently with panel data.

${ }^{13}$ See Chirinko (1988), Taylor (1989), and Chirinko, Fazzari, and Meyer (1999) regarding investment models and Rudebusch (2002) regarding monetary policy.
} 


\section{Model Selection}

We begin by examining the validity of our Autoregressive Distributed Lag $(\mathrm{ADL}(\mathrm{H}))$ model. Equation (2) is estimated with various lag lengths $(\mathrm{H})$ and alternative estimation techniques. We estimate ADL(2), ADL(3), and ADL(4) models by GMM. ${ }^{14}$ However, within the class of GMM estimators, there are at least three different techniques for generating consistent estimates in models with fixed effects and endogenous regressors. The most commonly used technique firstdifferences the model variables, and uses instrumental variables in levels (Arellano and Bond, 1991). The instruments are the undifferenced values of all regressors lagged at least two-periods (or more when feasible) -- that is,

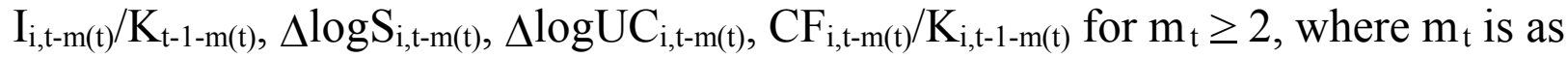
large as possible given data availability and increases over the sample; a constant and year dummies are also in the instrument set. A second approach that preserves the orthogonality between regressors and errors in the face of fixed effects reverses the above procedure, first-differencing the instruments but not transforming the regressors. Since the fixed effects no longer appear in the instrument list, they will not affect the estimated parameters. In this case, the instruments are the same as listed above except that they are first-differenced and $m_{t} \geq 1$. We refer to these two approaches as the First-Difference and Levels estimators, respectively. A third approach exploits additional orthogonality by combining the two approaches. This System estimator has been proposed by Arellano and Bover (1995) and Blundell and Bond (1998).

On a priori grounds, all three estimators are valid, and we employ two specification tests to select among the estimators and lag lengths. Sargan (1958) and Hansen (1982) propose a statistic (SH) for testing overidentifying restrictions. A second specification test examines residual serial correlation. With the FirstDifference estimator, white noise errors imply that the residuals between periods $t$ and $t-2$ will be uncorrelated. For the Levels estimator, the requirement pertains to the residuals between periods $t$ and $t-1$. We use the Lagrangian Multiplier statistic $(\operatorname{LM}(\mathrm{q}), \mathrm{q}=1,2)$ proposed by Arellano and Bond (1991) for testing $\mathrm{q}^{\text {th }}$-order residual serial correlation. If the model is correctly specified, the overidentifying restrictions will be sustained, and the residuals between periods $t$ and $t-q$ will be uncorrelated.

Table 4 contains the p-values for the SH and LM(q) statistics for the FirstDifference, Levels, and Systems estimators for the ADL(2), ADL(3), and ADL(4) models. Only the First-Difference/ADL(3) model has a SH statistic that exceeds the conventional 5\% level of significance. The LM statistic for this model of 0.165 suggests that residual serial correlation will not adversely affect

\footnotetext{
${ }^{14}$ All estimates are computed with DPD (Ox version 2.20 for Windows), and are the "two-step estimates" based on a weighting-matrix that is a function of the initial GMM parameter estimates.
} 


\section{Table 4: GMM Parameter Estimates Of Equation (2) Alternative ADL Lag Lengths And Estimators}

\begin{tabular}{|c|c|c|c|}
\hline & $\begin{array}{l}\text { First-Difference } \\
\text { (1) }\end{array}$ & $\begin{array}{l}\text { Levels } \\
\text { (2) }\end{array}$ & $\begin{array}{l}\text { System } \\
\text { (3) }\end{array}$ \\
\hline \multicolumn{4}{|l|}{$\Delta D L(2)$} \\
\hline SH p-value & 0.002 & 0.000 & 0.000 \\
\hline LM p-value & 0.008 & 0.000 & $0.000 / 0.000$ \\
\hline $\begin{array}{l}\eta_{\text {uc }} \\
\text { (std. dev.) }\end{array}$ & $\begin{array}{l}-0.445 \\
(0.106)\end{array}$ & $\begin{array}{l}-0.117 \\
(0.114)\end{array}$ & $\begin{array}{l}-0.193 \\
0.096\end{array}$ \\
\hline Observations & 27,195 & 38,442 & 35,677 \\
\hline Firms & 8,482 & 11,247 & 8,482 \\
\hline \multicolumn{4}{|l|}{$\Delta D L(3)$} \\
\hline SH p-value & 0.075 & 0.014 & 0.009 \\
\hline LM p-value & 0.165 & 0.000 & $0.000 / 0.106$ \\
\hline $\begin{array}{l}\eta_{\text {uc }} \\
\text { (std. dev.) }\end{array}$ & $\begin{array}{l}-0.401 \\
(0.144)\end{array}$ & $\begin{array}{l}-0.111 \\
(0.117) \\
\end{array}$ & $\begin{array}{l}-0.285 \\
(0.112)\end{array}$ \\
\hline Observations & 18,713 & 27,195 & 25,121 \\
\hline Firms & 6,408 & 8,482 & 6,408 \\
\hline \multicolumn{4}{|l|}{$\Delta D L(4)$} \\
\hline SH p-value & 0.009 & 0.020 & 0.000 \\
\hline LM p-value & 0.885 & 0.025 & $0.000 / 0.631$ \\
\hline $\begin{array}{l}\eta_{\text {uc }} \\
\text { (std. dev.) }\end{array}$ & $\begin{array}{l}-0.320 \\
(0.227)\end{array}$ & $\begin{array}{l}-0.152 \\
(0.139)\end{array}$ & $\begin{array}{l}-0.325 \\
(0.134)\end{array}$ \\
\hline Observations & 12,305 & 18,713 & 17,040 \\
\hline Firms & 4,735 & 6,408 & 4,735 \\
\hline
\end{tabular}

\section{Notes To Table 4:}

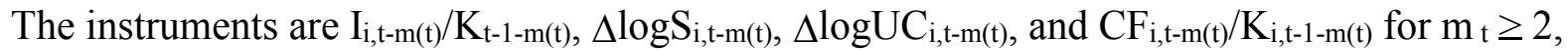
where $\mathrm{m}_{\mathrm{t}}$ is as large as possible given data availability and increases over the sample; a constant and $\tau_{\mathrm{t}}$ are also in the instrument set. Standard errors are in parentheses. In column 1, the model is first-differenced and the instruments are untransformed. In column 2, the model is untransformed, and the instruments are first-differenced. Column 3 combines the First-Differenced and Levels estimators. SH is the p-value for the Sargan-Hansen statistic testing overidentifying restrictions. $\mathrm{LM}$ is the $\mathrm{p}$-value for the Lagrange Multiplier statistic testing for $\mathrm{q}^{\text {th }}$-order autocorrelation: column (1), $\mathrm{q}=2$; column (2), $\mathrm{q}=1$; column ( 3 ), $\mathrm{q}=1 / \mathrm{q}=2$. $\eta_{\text {uc }}$ is the long-run elasticity for the user cost (see equation (3) in the text); standard errors computed by the delta method. An observation is defined by a "string" of datapoints needed to form a contiguous relation between the dependent and current and lagged independent and lagged dependent variables. Standard errors computed by the delta method. Section IV contains a further discussion of these statistics. 
the estimated parameters. Thus, the First-Difference/ADL(3) model is used for all subsequent estimates.

The long-run user cost elasticity ( $\eta_{\text {uc }}$ ) is a convenient summary statistic of price sensitivity, and allows us to gauge the response of capital formation to the interest rate embedded in the user cost. This elasticity is defined as the sum of the coefficients on the user cost variables divided by one minus the sum of the coefficients on the lagged dependent variables. ${ }^{15}$ (The standard error of $\eta_{\mathrm{uc}}$ is computed by the delta method.) In terms of the coefficients in equation (2), $\eta_{u c}$ is defined as follows,

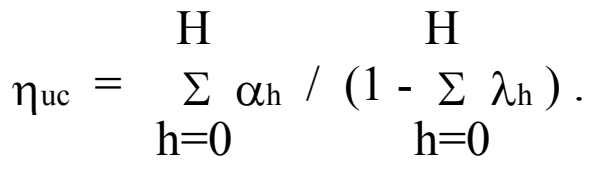

These statistics are also reported in Table 4. For a given estimator, the impacts of the user cost are robust to variations in the lag length. In column 1 for our preferred First-Difference model, the $\eta_{u c}$ 's range narrowly from -0.320 to -0.445 . For the First-Difference estimator, the impact of the interest rate on investment would not appear to be sensitive to lag length. However, estimates based on Levels or Systems estimators, which are statistically inappropriate in our sample, would lead to a substantial understatement.

\section{The Interest Rate Channel}

In this section, we assess the statistical and economic significance of the interest rate channel of monetary policy implied by our estimates. In the ADL investment model, the interest rate channel operates through the user cost. We begin by presenting the complete set of estimated coefficient and other statistics for our preferred ADL(3) model. As shown in column 1 of Table 5, the sums of the coefficients $\left(\Sigma_{\mathrm{h}} \mathrm{X}_{\mathrm{i}, \mathrm{th}}\right.$ for variable $\left.\mathrm{X}=\{\mathrm{UC}, \mathrm{S}, \mathrm{CF} / \mathrm{K}, \mathrm{I} / \mathrm{K}\}\right)$ and the long-run elasticities $\left(\eta_{\mathrm{x}}\right)$ for all regressors are statistically significant at the $1 \%$ level. ${ }^{16}$

The results in column 2 document the important interaction between cash flow and user cost variables. The cash flow variable is included in equation (2) to capture short-term financing effects. When the cash flow coefficients are

\footnotetext{
${ }^{15}$ If the production technology is CES and the identification assumptions in Appendix B are satisfied, $\eta_{\mathrm{uc}}$ is the price elasticity of the capital stock or, equivalently, the elasticity of substitution between labor and capital.

${ }^{16}$ The sum of coefficients accounts only for the direct effects of that variable on investment. The $\eta$ 's captures this effect in its numerator (cf. equation 3), as well as the dynamic impact of the coefficients from the lags of the dependent variable in its denominator. For sales and cash flow, the $\eta$ 's are defined by an expression very similar to (3) but with the $\alpha$ 's replaced by the $\beta$ 's and $\gamma$ 's estimated in equation (2), respectively. Note that $\eta_{\mathrm{cf}}$ is a semi-elasticity.
} 
Table 5: GMM Parameter Estimates Of Equation (2)

Dependent Variable: $I_{t} / K_{t-1}$

ADL(3) With The First-Difference Estimator

\begin{tabular}{|c|c|c|c|}
\hline Variable & $\begin{array}{c}\text { All Coefficients } \\
\text { (1) }\end{array}$ & $\begin{array}{l}\text { No Cash Flow } \\
\text { (2) }\end{array}$ & $\begin{array}{l}\text { Trimmed } \\
(3)\end{array}$ \\
\hline$\Delta \log \mathbf{U}_{\mathrm{i}, \mathrm{t}}$ & $\begin{array}{l}-0.207 \\
(0.071)\end{array}$ & $\begin{array}{c}-0.232 \\
(0.073)\end{array}$ & $\begin{array}{c}-0.209 \\
(0.069)\end{array}$ \\
\hline$\Delta \log \mathrm{UC}_{\mathrm{i}, \mathrm{t}-1}$ & $\begin{array}{c}-0.163 \\
(0.038)\end{array}$ & $\begin{array}{c}-0.190 \\
(0.039)\end{array}$ & $\begin{array}{l}-0.167 \\
(0.031)\end{array}$ \\
\hline$\Delta \log U C_{i, t-2}$ & $\begin{array}{c}-0.014 \\
(0.034)\end{array}$ & $\begin{array}{l}-0.037 \\
(0.034)\end{array}$ & \\
\hline$\Delta \log U C_{i, t-3}$ & $\begin{array}{c}0.038 \\
(0.027)\end{array}$ & $\begin{array}{c}0.022 \\
(0.028)\end{array}$ & \\
\hline$\Sigma_{\mathbf{h}} \Delta \log \mathbf{U} \mathbf{C}_{\mathrm{i}, \mathrm{th}}$ & $\begin{array}{c}-0.347 \\
(0.125)\end{array}$ & $\begin{array}{r}-0.437 \\
(0.126)\end{array}$ & $\begin{array}{c}-0.376 \\
(0.088)\end{array}$ \\
\hline$\eta_{\text {uc }}$ & $\begin{array}{c}-0.401 \\
(0.145)\end{array}$ & $\begin{array}{c}-0.522 \\
(0.151)\end{array}$ & $\begin{array}{c}-0.435 \\
(0.103)\end{array}$ \\
\hline$\Delta \log S_{i, t}$ & $\begin{array}{c}0.161 \\
(0.055) \\
\end{array}$ & $\begin{array}{c}0.191 \\
(0.055)\end{array}$ & $\begin{array}{c}0.141 \\
(0.052)\end{array}$ \\
\hline$\Delta \log \mathrm{S}_{\mathrm{i}, \mathrm{t}-1}$ & $\begin{array}{c}0.095 \\
(0.014)\end{array}$ & $\begin{array}{c}0.115 \\
(0.013)\end{array}$ & $\begin{array}{c}0.090 \\
(0.014)\end{array}$ \\
\hline$\Delta \log S_{i, t-2}$ & $\begin{array}{c}0.065 \\
(0.011)\end{array}$ & $\begin{array}{c}0.080 \\
(0.011)\end{array}$ & $\begin{array}{c}0.062 \\
(0.011)\end{array}$ \\
\hline$\Delta \log S_{i, t-3}$ & $\begin{array}{c}0.033 \\
(0.010) \\
\end{array}$ & $\begin{array}{c}0.041 \\
(0.010)\end{array}$ & $\begin{array}{c}0.034 \\
(0.009) \\
\end{array}$ \\
\hline$\sum_{\mathbf{h}} \Delta \log \mathrm{S}_{\mathrm{i}, \mathrm{t}-\mathrm{h}}$ & $\begin{array}{c}0.354 \\
(0.068)\end{array}$ & $\begin{array}{c}0.427 \\
(0.064)\end{array}$ & $\begin{array}{c}0.328 \\
(0.065) \\
\end{array}$ \\
\hline$\eta_{\mathrm{s}}$ & $\begin{array}{c}0.409 \\
(0.077)\end{array}$ & $\begin{array}{c}0.510 \\
(0.076)\end{array}$ & $\begin{array}{c}0.380 \\
(0.075)\end{array}$ \\
\hline $\mathbf{C} F_{i, t} / K_{i, t-1}$ & $\begin{array}{c}0.070 \\
(0.034)\end{array}$ & & $\begin{array}{c}0.094 \\
(0.024)\end{array}$ \\
\hline $\mathbf{C F}_{\mathrm{i}, \mathrm{t}-1} / \mathbf{K}_{\mathrm{i}, \mathrm{t}-2}$ & $\begin{array}{c}0.013 \\
(0.014)\end{array}$ & & \\
\hline $\mathbf{C F}_{\mathrm{i}, \mathrm{t}-2} / \mathbf{K}_{\mathrm{i}, \mathrm{t}-\mathbf{3}}$ & $\begin{array}{c}0.005 \\
(0.005) \\
\end{array}$ & & \\
\hline $\mathbf{C} F_{i, t-3} / K_{i, t-4}$ & $\begin{array}{c}0.005 \\
(0.004)\end{array}$ & & \\
\hline$\Sigma_{\mathrm{h}} \mathrm{CF} \mathrm{F}_{\mathrm{it}-\mathrm{h}} / \mathrm{K}_{\mathrm{it}-\mathrm{h}-\mathbf{1}}$ & $\begin{array}{c}0.093 \\
(0.025)\end{array}$ & & $\begin{array}{c}0.094 \\
(0.024)\end{array}$ \\
\hline$\eta_{\mathbf{c f}}$ & $\begin{array}{c}0.108 \\
(0.029)\end{array}$ & & $\begin{array}{c}0.109 \\
(0.027)\end{array}$ \\
\hline
\end{tabular}




\section{Table 5: GMM Parameter Estimates Of Equation (2) (cont.) Dependent Variable: $\mathbf{I}_{t} / \mathbf{K}_{\mathrm{t}-1}$ ADL(3) And Alternative Estimators}

\begin{tabular}{|c|c|c|c|}
\hline Variable & $\begin{array}{c}\text { All Coefficients } \\
\text { (1) }\end{array}$ & $\begin{array}{c}\text { No Cash Flow } \\
(2)\end{array}$ & $\begin{array}{r}\text { Trimmed } \\
\text { (3) }\end{array}$ \\
\hline $\mathbf{I}_{\mathbf{i}, \mathbf{t}-1} / \mathbf{K}_{\mathrm{i}, \mathrm{t}-1}$ & $\begin{array}{c}0.131 \\
(0.016)\end{array}$ & $\begin{array}{c}0.148 \\
(0.016)\end{array}$ & $\begin{array}{c}0.136 \\
(0.014) \\
\end{array}$ \\
\hline $\mathbf{I}_{\mathrm{i}, \mathrm{t}-\mathbf{2}} / \mathbf{K}_{\mathrm{i}, \mathrm{t}-2}$ & $\begin{array}{l}-0.002 \\
(0.009)\end{array}$ & $\begin{array}{c}0.005 \\
(0.009)\end{array}$ & \\
\hline $\mathbf{I}_{\mathbf{i}, \mathbf{t}-\mathbf{3}} / \mathbf{K}_{\mathbf{i}, \mathbf{t}-3}$ & $\begin{array}{c}0.005 \\
(0.007)\end{array}$ & $\begin{array}{c}0.009 \\
(0.007)\end{array}$ & \\
\hline$\Sigma_{\mathbf{h}} \mathbf{I}_{\mathbf{i}, \mathbf{t}-\mathbf{j}} / \mathbf{K}_{\mathbf{i}, \mathbf{t}-\mathbf{h}-\mathbf{1}}$ & $\begin{array}{c}0.135 \\
(0.025)\end{array}$ & $\begin{array}{c}0.163 \\
(0.025)\end{array}$ & $\begin{array}{c}0.136 \\
(0.014)\end{array}$ \\
\hline SH p-value & 0.075 & 0.048 & 0.092 \\
\hline LM p-value & 0.165 & 0.240 & 0.118 \\
\hline Observations & 18,713 & 18,713 & 18,713 \\
\hline Firms & 6,408 & 6,408 & 6,408 \\
\hline
\end{tabular}

Notes To Table 5:

See the note to Table 1 for variable definitions. Constants $\left(\zeta_{\mathrm{i}}\right)$ and year dummies $\left(\tau_{\mathrm{t}}\right)$ are also

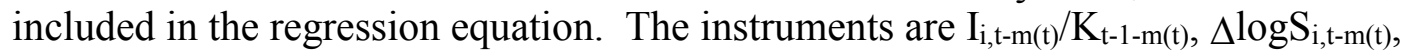

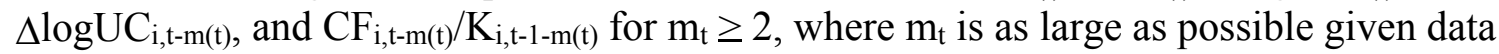
availability and increases over the sample; a constant and $\tau_{\mathrm{t}}$ are also in the instrument set. Heteroscedastic-consistent standard errors are in parentheses. Column 1 is based on the ADL(3) with all lag coefficients. Column 2 excludes the $\mathrm{CF} / \mathrm{K}$ regressors. Column 3 excludes those regressors in column 1 with t-statistics whose $\mathrm{p}$-values are greater than $0.10 . \Sigma_{\mathrm{h}} \mathrm{X}_{\mathrm{i}, \mathrm{t}-\mathrm{h}}$ is the sum of coefficients for variable $\mathrm{X}=\{\mathrm{UC}, \mathrm{S}, \mathrm{CF} / \mathrm{K}, \mathrm{I} / \mathrm{K}\} . \eta \mathrm{X}$ is the long-run elasticity for variable $\mathrm{X}$ (see equation (3) in the text); standard errors are computed by the delta method. SH is the p-value for the Sargan-Hansen statistic testing overidentifying restrictions. LM is the p-value for the Lagrange Multiplier statistic testing for second-order autocorrelation. An observation is defined by a "string" of datapoints needed to form a contiguous relation between the dependent and current and lagged independent and lagged dependent variables. Standard errors computed by the delta method. Section IV contains a further discussion of these statistics.

constrained to zero, the absolute value of $\eta_{\text {uc }}$ rises by $30 \%$. This change can be interpreted as an "income effect" induced by financing constraints (Chirinko, Fazzari, and Meyer, 1999). For a firm operating in frictionless capital markets, a user cost change induces only a substitution effect. However, interest costs and available internal finance are also affected by interest rates. Fluctuations in internal finance can affect the behavior of financially constrained firms over and above the 
effects arising from substitution alone. A higher interest rate may have standard incentive effects on the demand for capital and investment but, for financially constrained firms, the resulting decline in cash flow could reduce investment further than if the firm operated in perfect capital markets.

This interpretation of "income effects" is consistent with our findings in columns 1 and 2 . In the regression without cash flow (column 2), $\eta_{\text {uc }}$ captures both the conventional substitution effect and the income effect induced by financing constraints, which affect investment in the same direction. However, when we add cash flow (column 1), the lower absolute value of $\eta_{\text {uc }}$ can be interpreted as the user cost elasticity holding cash flow constant; that is, as a measure of the conventional substitution effect alone.

Before investigating the credit channel, we note that there are several insignificant coefficients in the distributed lags that may affect the reported standard errors for the estimated coefficients, sums, and elasticities. To obtain more precise estimates, we proceed to remove those variables from the model in column 1 whose $\mathrm{t}$-statistics have a $\mathrm{p}$-value that is greater than 0.10 . This trimmed specification includes one lag of the dependent variable, the current value of cash flow, the current and one lagged value of the user cost, and the current and three lagged values of sales. These trimmed estimates are presented in column 3 of Table 6 . Relative to the results in column 1, the point estimates are quite robust, and are estimated more precisely. Trimmed models will be the primary focus of the subsequent analysis.

The estimates of the UC coefficients in Table 5 establish that the interest rate channel for business fixed investment is statistically significant. In the remaining part of this section, we analyze its economic significance by evaluating the impact of an expansionary monetary policy that lowers the short-term nominal interest rate by 100 basis points over two years with no offsetting increase in inflation. In our framework, the effect on investment is transitory. We assume that the central bank can not permanently change the real interest rate. This assumption, coupled with the investment equation specification containing the growth rate in the user cost (see Appendix B for the derivation), implies that monetary policy can not affect the longrun capital stock. In the spirit of our partial equilibrium exercise, we further assume that all of the remaining variables are unaltered by the monetary policy. Thus it is important to bear in mind that we are not presenting a total assessment of the effects of monetary policy.

To understand the key assumptions in our evaluation, consider the highly stylized, static investment equation drawn from equations (1) and (2),

$$
\begin{aligned}
& \mathrm{I} / \mathrm{K}=-\alpha \log \mathrm{UC} \\
& \mathrm{UC}=(\mathrm{i}[\mathrm{m}]-\pi+\delta) * \mathrm{P} * \mathrm{~T},
\end{aligned}
$$


where $\mathrm{m}$ is the short-term interest rate controlled by the monetary authority. The percentage change in investment $(\Delta \mathrm{I} / \mathrm{I})$ with respect to a monetary impulse $(\Delta \mathrm{m})$ is computed from (4),

$$
\begin{aligned}
& \Delta \mathrm{I} / \mathrm{K}=-\alpha((\mathrm{MUC} / \mathrm{Mi}) / \mathrm{UC})(\mathrm{di} / \mathrm{dm}) \Delta \mathrm{m} \\
& \Delta \mathrm{I} / \mathrm{K} *(\mathrm{~K} / \mathrm{I})=-\alpha(\mathrm{K} / \mathrm{I})(\mathrm{P} * \mathrm{~T}) /\left((\mathrm{i}[\mathrm{m}]-\pi+\delta)^{*} \mathrm{P} * \mathrm{~T}\right)(\mathrm{di} / \mathrm{dm}) \Delta \mathrm{m}, \\
& \Delta \mathrm{I} / \mathrm{I}=-\alpha(\mathrm{I} / \mathrm{K} *(\mathrm{i}[\mathrm{m}]-\pi+\delta))^{-1}(\mathrm{di} / \mathrm{dm}) \Delta \mathrm{m} .
\end{aligned}
$$

The right side of equation (5c) is quantified as follows. The $\alpha$ is from row 1 , column 3 of Table 5 , and equals -0.209 . The $(\delta *(\mathrm{i}[\mathrm{m}]-\pi+\delta))^{-1}$ term varies across firms and time, and the mean value computed from the sample equals 18.66. The long-term rate (which enters the user cost) is assumed to move one-for-one with the short-term rate controlled by the monetary authorities; hence $(\mathrm{di} / \mathrm{dm})=1$. Lastly, the monetary policy experiment is a 100 basis point cut; hence, $\Delta \mathrm{m}=-0.01$.

With these assumptions, investment increases by $3.90 \%$ in the first year. The above computations are applicable to the second year by replacing the $\alpha$ with the coefficient on the lagged user cost variable (-0.167) and accounting for the effect of the lagged dependent variable. Over two years, investment would increase by about $7.55 \%$. Since investment is approximately $18.00 \%$ of GDP, this increment corresponds to about a $1.40 \%$ increase in GDP. Under this computation, the interest rate channel of monetary policy is economically significant.

However, it is important to realize that the above computations depend critically on the expectation assumptions reflected in the term structure of interest rates. The response $(\mathrm{di} / \mathrm{dm})$ of the long-term rate (influencing investment through the user cost) to the short-term rate (controlled by the central bank) can have important impacts on the results. There is some evidence that $\mathrm{di} / \mathrm{dm}$ may be less than unity. ${ }^{18}$ Bernanke, Gertler, and Watson (1997, p. 115) examine the relation between short-term and long-term rates, and find that $\mathrm{di} / \mathrm{dm}=0.20$. With this assumption, the above responses of investment and GDP fall by a factor of 5 . In sum, while our results indicate a statistically significant monetary policy channel, its economic significance depends on auxiliary assumptions that are outside the scope

\footnotetext{
${ }^{17}$ Note that this formulation does not allow the present value of depreciation allowances (" $\mathrm{A}$ " in Appendix A) to vary with the interest rate due to computational considerations and a desire to separate fiscal and monetary policy issues.

${ }^{18}$ It may be difficult to represent the term structure response with a single parameter. The relation will highly depend on agents' inferences from present policy to future policy. These inferences depend on the current stance of monetary policy in relation to current macroeconomic conditions, and hence are likely to change over time.
} 
of the present study. At this point, assessments of economic significance must be made with due caution.

\section{The Credit Channel}

Monetary policy can also affect firms through a credit channel, and our data on creditworthiness and user costs allow us to offers some important new evidence. While the literature has been characterized by sharp differences of opinion, there is rather broad agreement that variations in firm creditworthiness and the resulting wedge between internal and external finance are the key elements in models of credit constraints. ${ }^{19}$ Two hypotheses are examined. First, as in many prior studies, we evaluate the importance of credit constraints by the differential sensitivity to cash flow among firms sorted by their creditworthiness. This sorting directly focuses on the fundamental element in the credit constraints literature, the external finance premium. A second hypothesis is that financially constrained firms should not be responsive to price incentives because of rationing in credit markets (Stiglitz and Weiss, 1981; Williamson, 1987). This differential sensitivity to the user cost has not been tested previously, perhaps owing to a lack of suitable user cost data. ${ }^{20}$ With respect to the two sensitivity tests, credit constrained firms should be relatively more sensitive to cash flow and relatively less sensitive to the user cost.

The standard approach in the literature is to sort firms into contrasting classes differentiated by some indicator variable for their external finance premium. This approach has been the subject of recent criticism for using indirect and potentially misleading indicator. ${ }^{21}$ However, our direct measure of creditworthiness allow us to avoid this problem, and generate powerful tests of credit constraints. We also provide additional sortings of our sample based on firm size and dividend payout ratios that shed some additional light on debates in the literature.

\section{A. Sorting By Creditworthiness}

Our first split sample estimates are based on a sorting defined by a direct measure of the external finance premium, CWR. Firms are sorted into three categories of creditworthiness -- Endangered, Good, and Indeterminate -- depending on the state in the year before the investment/capital ratio first enters the regression model as a dependent variable. Our large sample permits us to discard the middle group to in order to sharpen the tests. Estimates for the Endangered and Good

${ }^{19}$ For example, Fazzari, Hubbard, and Petersen (1988, p. 183), Kaplan and Zingales (1997, pp. 172-173), and Bernanke and Gertler (1990, pp. 88-89).

${ }^{20}$ Interestingly, the test was proposed at the beginning of the recent renaissance in credit constraint studies; see the discussion by Blinder (1988) of Fazzari, Hubbard, and Peterson (1988).

${ }^{21}$ See Kaplan and Zingales (1997, 2000), the reply by Fazzari, Hubbard, and Petersen (2000), and the surveys by Hubbard (1998) and Schiantarelli (1995). 
classes of firms are presented in Table 6. The full ADL(3) model is presented in columns 1 and 2. We introduce two new statistics -- $\psi_{\mathrm{x}}$ and $\phi_{\mathrm{x}}$, where $\mathrm{X}$ refers to a model variable -- to assess the differences between the $\left(\Sigma_{\mathrm{j}} \mathrm{X}_{\mathrm{i}, \mathrm{t}-\mathrm{j}}\right)$ 's and the $\eta_{\mathrm{x}}$ 's, respectively, for the Endangered and Good firms. Trimmed estimates are presented in columns 3 and 4, and will be the focus of the subsequent discussion.

The CWR split sample results offer striking confirmation of the importance of finance constraints. As shown in Table 6, the sum of cash flow coefficients of 0.154 for the firms with questionable creditworthiness is more than twice as large the comparable coefficient of 0.075 for Good firms. (A similar result holds for the $\eta_{\mathrm{cf}}$ 's.) The null hypothesis of equality is assessed by $\psi \mathrm{cf}$, and is rejected with a pvalue of 0.03 . More dramatic results are forthcoming for our second test on the user cost variable. The sum of -0.047 for Endangered firms is not different from zero; for financially constrained firms, the interest rate channel appears to "shut down". The comparable estimate for Good firms is -0.459 with a standard error of 0.100 . The null hypothesis of the equality of these sums is again rejected. Thus, both differential sensitivity tests point to the conclusion that credit constraints are important for German firms.

B. Sorting By Firm Size

Firm size has been frequently used to identify credit constrained firms. Small firms arguably face financing problems because they have less visibility in external capital markets and are poorly positioned to bear the fixed cost associated with external finance. A firm is categorized as Small if it has 100 or fewer employees on average over the sample; the complementary class defines Large firms. Since nearly one-half of our firms are Small, our tests should be able to detect small firm financing problems if they exist.

Table 7 contains the results for the size sorting. We again focus on the Trimmed results in columns 3 and 4 that have smaller standard errors and hence a greater chance of rejecting the null hypothesis. Small firms have relatively larger cash flow coefficients. However, the difference is not statistically significant ( $\psi \mathrm{cf}$ has a p-value of 0.17 ). For the second differential sensitivity test, the results contradict the credit constraints hypothesis. The user cost coefficient sum is relatively greater (in absolute value) for the Small and presumably constrained firms. The difference in user cost sums is not statistically significant.

These results suggest one of two conclusions. Coupled with the creditworthiness split sample results, some doubt is cast on whether firm size is useful in identifying credit constrained firms. ${ }^{22}$ Alternatively, it may be the case

\footnotetext{
${ }^{22}$ Size has generated mixed results. For example, Bernanke, Gertler, and Gilchrist (1996) find that small firms are credit constrained. In contrast, Oliner and Rudebusch (1992) report that size has no statistically significant effect in an investment equation, and Erickson and Whited (2000) find that cash flow coefficients for large and small firms are not statistically different.
} 
Table 6: GMM Parameter Estimates Of Equation (2)

Dependent Variable: $I_{t} / K_{t-1}$

ADL(3) With The First-Difference Estimator

Sub-Samples Defined By The Creditworthiness Ratio

\begin{tabular}{|c|c|c|c|c|}
\hline \multirow[b]{2}{*}{ Variable } & \multicolumn{2}{|c|}{ ALL COEEFICIENTS } & \multicolumn{2}{|c|}{ TRIMMED COEFEICIENTS } \\
\hline & $\begin{array}{c}\text { Endangered } \\
\text { (1) }\end{array}$ & $\begin{array}{c}\text { Good } \\
\text { (2) }\end{array}$ & $\begin{array}{c}\text { Endangered } \\
\text { (3) }\end{array}$ & $\begin{array}{c}\text { Good } \\
(4)\end{array}$ \\
\hline$\Delta \log \mathrm{UC}_{\mathrm{i}, \mathrm{t}}$ & $\begin{array}{c}0.012 \\
(0.131)\end{array}$ & $\begin{array}{l}-0.309 \\
(0.082)\end{array}$ & $\begin{array}{c}0.035 \\
(0.127)\end{array}$ & $\begin{array}{l}-0.288 \\
(0.079)\end{array}$ \\
\hline$\Delta \log \mathrm{UC}_{\mathrm{i}, \mathrm{t}-1}$ & $\begin{array}{r}-0.104 \\
(0.079)\end{array}$ & $\begin{array}{l}-0.193 \\
(0.043)\end{array}$ & $\begin{array}{l}-0.082 \\
(0.063)\end{array}$ & $\begin{array}{l}-0.171 \\
(0.036)\end{array}$ \\
\hline$\Delta \log U C_{i, t-2}$ & $\begin{array}{l}-0.086 \\
(0.072)\end{array}$ & $\begin{array}{l}-0.050 \\
(0.036)\end{array}$ & & \\
\hline$\Delta \log \mathrm{U}_{\mathrm{i}, \mathrm{t}-\mathrm{3}}$ & $\begin{array}{c}0.009 \\
(0.054)\end{array}$ & $\begin{array}{c}0.008 \\
(0.030)\end{array}$ & & \\
\hline \multirow[t]{2}{*}{$\Sigma_{\mathbf{j}} \Delta \log \mathbf{U} \mathbf{C}_{\mathrm{i}, \mathrm{t}-\mathrm{j}}$} & $\begin{array}{r}-0.170 \\
(0.254)\end{array}$ & $\begin{array}{l}-0.544 \\
(0.139)\end{array}$ & $\begin{array}{l}-0.047 \\
(0.170)\end{array}$ & $\begin{array}{l}-0.459 \\
(0.100)\end{array}$ \\
\hline & \multicolumn{2}{|c|}{$\begin{aligned} \psi \mathbf{u c}= & 0.373 \\
& (0.290)\end{aligned}$} & \multicolumn{2}{|c|}{$\psi_{\text {uc }}=0.411$} \\
\hline \multirow[t]{2}{*}{$\eta_{\text {uc }}$} & $\begin{array}{r}-0.189 \\
(0.283)\end{array}$ & $\begin{array}{l}-0.608 \\
(0.157)\end{array}$ & $\begin{array}{r}-0.054 \\
(0.194)\end{array}$ & $\begin{array}{l}-0.524 \\
(0.115)\end{array}$ \\
\hline & \multicolumn{2}{|c|}{$\begin{aligned} \phi_{\text {uc }}= & 0.419 \\
& (0.324)\end{aligned}$} & \multicolumn{2}{|c|}{$\begin{aligned} \phi \mathbf{u c}= & 0.470 \\
& (0.225)\end{aligned}$} \\
\hline$\Delta \log S_{i, t}$ & $\begin{array}{c}0.044 \\
(0.059)\end{array}$ & $\begin{array}{c}0.220 \\
(0.065)\end{array}$ & $\begin{array}{l}-0.001 \\
(0.054)\end{array}$ & $\begin{array}{c}0.209 \\
(0.061)\end{array}$ \\
\hline$\Delta \log \mathrm{S}_{\mathrm{i}, \mathrm{t}-1}$ & $\begin{array}{r}0.043 \\
(0.022)\end{array}$ & $\begin{array}{c}0.112 \\
(0.017)\end{array}$ & $\begin{array}{c}0.042 \\
(0.022)\end{array}$ & $\begin{array}{c}0.108 \\
(0.017)\end{array}$ \\
\hline$\Delta \log S_{i, t-2}$ & $\begin{array}{c}0.021 \\
(0.018)\end{array}$ & $\begin{array}{c}0.063 \\
(0.014)\end{array}$ & $\begin{array}{c}0.022 \\
(0.018)\end{array}$ & $\begin{array}{c}0.060 \\
(0.013)\end{array}$ \\
\hline$\Delta \log S_{i, t-3}$ & $\begin{array}{c}0.031 \\
(0.015)\end{array}$ & $\begin{array}{c}0.031 \\
(0.011)\end{array}$ & $\begin{array}{c}0.028 \\
(0.015)\end{array}$ & $\begin{array}{c}0.030 \\
(0.011)\end{array}$ \\
\hline \multirow[t]{2}{*}{$\Sigma_{\mathbf{j}} \Delta \log \mathrm{S}_{\mathrm{i}, \mathrm{t}-\mathrm{j}}$} & $\begin{array}{c}0.140 \\
(0.087)\end{array}$ & $\begin{array}{c}0.427 \\
(0.077) \\
\end{array}$ & $\begin{array}{c}0.091 \\
(0.083)\end{array}$ & $\begin{array}{c}0.408 \\
(0.073)\end{array}$ \\
\hline & \multicolumn{2}{|c|}{$\begin{aligned} \psi s & =-0.287 \\
& (0.116)\end{aligned}$} & \multicolumn{2}{|c|}{$\begin{aligned} \mathrm{s}= & =-0.318 \\
& (0.111)\end{aligned}$} \\
\hline \multirow[t]{2}{*}{$\eta_{\mathrm{s}}$} & $\begin{array}{c}0.156 \\
(0.098)\end{array}$ & $\begin{array}{c}0.478 \\
(0.085)\end{array}$ & $\begin{array}{c}0.103 \\
(0.095)\end{array}$ & $\begin{array}{c}0.467 \\
(0.083)\end{array}$ \\
\hline & \multicolumn{2}{|c|}{$\begin{aligned} \phi \mathbf{s}= & -0.322 \\
& (0.130)\end{aligned}$} & \multicolumn{2}{|c|}{$\begin{aligned} \phi s= & -0.363 \\
& (0.126)\end{aligned}$} \\
\hline
\end{tabular}


Table 6: GMM Parameter Estimates Of Equation (2)

(cont.) Dependent Variable: $I_{t} / K_{t-1}$

ADL(3) With The First-Difference Estimator Sub-Samples Defined By The Creditworthiness Ratio

\begin{tabular}{|c|c|c|c|c|}
\hline \multirow[b]{2}{*}{ Variable } & \multicolumn{2}{|c|}{ ALL COEFEICIENTS } & \multicolumn{2}{|c|}{ TRIMMED COEFEICIENTS } \\
\hline & \multicolumn{2}{|c|}{$\begin{array}{c}\text { Endangered } \\
(1) \\
\end{array}$} & \multicolumn{2}{|c|}{$\begin{array}{c}\text { Endangered } \\
(\mathbf{3}) \\
\end{array}$} \\
\hline $\mathrm{CF}_{\mathrm{i}, \mathrm{t}} / \mathrm{K}_{\mathrm{i}, \mathrm{t}-1}$ & $\begin{array}{c}0.142 \\
(0.030)\end{array}$ & $\begin{array}{c}0.071 \\
(0.034)\end{array}$ & $\begin{array}{c}0.154 \\
(0.028)\end{array}$ & $\begin{array}{c}0.075 \\
(0.023)\end{array}$ \\
\hline$C F_{i, t-1} / K_{i, t-2}$ & $\begin{array}{r}0.018 \\
(0.013) \\
\end{array}$ & $\begin{array}{r}0.005 \\
(0.016) \\
\end{array}$ & & \\
\hline$C F_{i, t-2} / K_{i, t-3}$ & $\begin{array}{c}0.010 \\
(0.008)\end{array}$ & $\begin{array}{r}0.005 \\
(0.006)\end{array}$ & & \\
\hline$C F_{i, t-3} / K_{i, t-4}$ & $\begin{array}{l}-0.007 \\
(0.005)\end{array}$ & $\begin{array}{c}0.003 \\
(0.005)\end{array}$ & & \\
\hline \multirow[t]{2}{*}{$\Sigma_{\mathbf{j}} \mathbf{C} \mathbf{F}_{\mathrm{i}, \mathrm{t}-\mathrm{j}} / \mathbf{K}_{\mathrm{i}, \mathrm{t}-\mathrm{j}-\mathbf{1}}$} & $\begin{array}{r}0.163 \\
(0.034) \\
\end{array}$ & $\begin{array}{l}0.082 \\
(0.026) \\
\end{array}$ & $\begin{array}{c}0.154 \\
(0.028)\end{array}$ & $\begin{array}{r}0.075 \\
(0.023) \\
\end{array}$ \\
\hline & \multicolumn{2}{|c|}{$\begin{aligned} \psi \mathbf{C F}= & 0.081 \\
& (0.043)\end{aligned}$} & \multicolumn{2}{|c|}{$\begin{aligned} \psi C F & =0.079 \\
& (0.036)\end{aligned}$} \\
\hline \multirow[t]{2}{*}{$\eta_{C F}$} & $\begin{array}{c}0.181 \\
(0.039)\end{array}$ & $\begin{array}{c}0.092 \\
(0.029)\end{array}$ & $\begin{array}{c}0.175 \\
(0.033)\end{array}$ & $\begin{array}{c}0.086 \\
(0.026)\end{array}$ \\
\hline & \multicolumn{2}{|c|}{$\begin{array}{rl}\phi C F & 0.089 \\
& (0.049)\end{array}$} & \multicolumn{2}{|c|}{$\begin{aligned} \phi C F= & 0.089 \\
& (0.042)\end{aligned}$} \\
\hline $\mathbf{I}_{\mathbf{i}, \mathbf{t}-\mathbf{1}} / \mathbf{K}_{\mathbf{i}, \mathbf{t}-\mathbf{1}}$ & $\begin{array}{r}0.103 \\
(0.031) \\
\end{array}$ & $\begin{array}{r}0.114 \\
(0.017) \\
\end{array}$ & $\begin{array}{c}0.119 \\
(0.024)\end{array}$ & $\begin{array}{r}0.125 \\
(0.015) \\
\end{array}$ \\
\hline $\mathbf{I}_{\mathrm{i}, \mathrm{t}-2} / \mathbf{K}_{\mathrm{i}, \mathrm{t}-2}$ & $\begin{array}{r}-0.013 \\
(0.016)\end{array}$ & $\begin{array}{r}-0.011 \\
(0.010)\end{array}$ & & \\
\hline $\mathbf{I}_{\mathbf{i}, \mathbf{t}-\mathbf{3}} / \mathbf{K}_{\mathbf{i}, \mathbf{t}-\mathbf{3}}$ & $\begin{array}{r}0.010 \\
(0.012) \\
\end{array}$ & $\begin{array}{r}0.003 \\
(0.008) \\
\end{array}$ & & \\
\hline \multirow[t]{2}{*}{$\Sigma_{\mathbf{j}} \mathbf{I}_{\mathbf{i}, \mathrm{t}-\mathbf{j}} / \mathbf{K}_{\mathbf{i}, \mathbf{t}-\mathbf{j}-\mathbf{1}}$} & $\begin{array}{c}0.100 \\
(0.048)\end{array}$ & $\begin{array}{c}0.106 \\
(0.027)\end{array}$ & $\begin{array}{r}0.119 \\
(0.024)\end{array}$ & $\begin{array}{c}0.125 \\
(0.015)\end{array}$ \\
\hline & \multicolumn{2}{|c|}{$\begin{aligned} \psi \mathrm{IK}= & -0.005 \\
& (0.055)\end{aligned}$} & \multicolumn{2}{|c|}{$\begin{aligned} \psi I \mathrm{IK}= & -0.006 \\
& (0.028)\end{aligned}$} \\
\hline SH p-value & \multicolumn{2}{|c|}{0.239} & \multicolumn{2}{|c|}{0.326} \\
\hline LM p-value & \multicolumn{2}{|c|}{0.132} & \multicolumn{2}{|c|}{0.042} \\
\hline Observations & \multicolumn{2}{|c|}{16,256} & \multicolumn{2}{|c|}{16,256} \\
\hline Firms & \multicolumn{2}{|c|}{5,515} & \multicolumn{2}{|c|}{5,515} \\
\hline
\end{tabular}


Notes To Table 6:

See the note to Table 1 for variable definitions. Constants $\left(\zeta_{\mathrm{i}}\right)$ and year dummies $\left(\tau_{\mathrm{t}}\right)$ are also

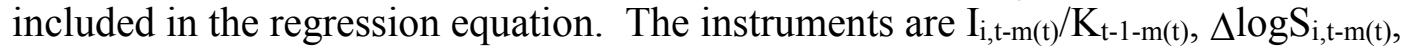
$\Delta \log \mathrm{UC}_{\mathrm{i}, \mathrm{t}-\mathrm{m}(\mathrm{t})}$, and $\mathrm{CF}_{\mathrm{i}, \mathrm{t}-\mathrm{m}(\mathrm{t})} / \mathrm{K}_{\mathrm{i}, \mathrm{t}-1-\mathrm{m}(\mathrm{t})}$ for $\mathrm{m}_{\mathrm{t}} \geq 2$, where $\mathrm{m}_{\mathrm{t}}$ is as large as possible given data availability and increases over the sample; a constant and $\tau_{\mathrm{t}}$ are also in the instrument set.

Heteroscedastic-consistent standard errors are in parentheses. The estimates in columns 1 and 2 are sorted by CWR : Endangered [Good] are those observations below [above] the lower [higher] critical value of CWR; Indeterminate observations have been excluded. The estimates in column 3 [4] exclude those regressors in column 1 [2] with t-statistics whose p-values are greater than 0.10 . $\Sigma_{\mathrm{h}} \mathrm{X}_{\mathrm{i}, \mathrm{t}-\mathrm{h}}$ is the sum of coefficients for variable $\mathrm{X}=\{\mathrm{UC}, \mathrm{S}, \mathrm{CF} / \mathrm{K}, \mathrm{I} / \mathrm{K}\} . \eta_{\mathrm{X}}$ is the long-run elasticity for variable $\mathrm{X}$ (see equation (3) in the text); standard errors are computed by the delta method. $\psi \mathrm{X}$ $[\phi x]$ is the difference between the $\left(\Sigma_{\mathrm{j}} \Delta \log \mathrm{X}_{\mathrm{i}, \mathrm{t}-\mathrm{j}}\right)$ 's $[\eta \mathrm{x}$ 's] for the Endangered [Good] firms. SH is the $p$-value for the Sargan-Hansen statistic testing overidentifying restrictions. LM is the p-value for the Lagrange Multiplier statistic testing for second-order autocorrelation. An observation is defined by a "string" of datapoints needed to form a contiguous relation between the dependent and current and lagged independent and lagged dependent variables. Section IV contains a further discussion of these statistics.

\section{Table 7: GMM Parameter Estimates Of Equation (2) Dependent Variable: $I_{t} / K_{t-1}$ ADL(3) With The First-Difference Estimator Sub-Samples Defined By Firm Size}

\begin{tabular}{|c|c|c|c|c|}
\hline \multirow[b]{2}{*}{ Variable } & \multicolumn{2}{|c|}{ ALL COEFEICIENTS } & \multicolumn{2}{|c|}{ TRIMMED COEFEICIENTS } \\
\hline & $\begin{array}{l}\text { Small } \\
\text { (1) }\end{array}$ & $\begin{array}{c}\text { Large } \\
\text { (2) }\end{array}$ & $\begin{array}{l}\text { Small } \\
(3)\end{array}$ & $\begin{array}{l}\text { Large } \\
\text { (4) }\end{array}$ \\
\hline$\Delta \log \mathrm{UC}_{\mathrm{i}, \mathrm{t}}$ & $\begin{array}{l}-0.350 \\
(0.125)\end{array}$ & $\begin{array}{l}-0.090 \\
(0.066)\end{array}$ & $\begin{array}{l}-0.336 \\
(0.121)\end{array}$ & $\begin{array}{l}-0.079 \\
(0.064)\end{array}$ \\
\hline$\Delta \log \mathrm{UC}_{\mathrm{i}, \mathrm{t}-1}$ & $\begin{array}{l}-0.193 \\
(0.066)\end{array}$ & $\begin{array}{l}-0.157 \\
(0.038)\end{array}$ & $\begin{array}{l}-0.173 \\
(0.049)\end{array}$ & $\begin{array}{l}-0.147 \\
(0.033)\end{array}$ \\
\hline$\Delta \log \mathbf{U C}_{\mathrm{i}, \mathrm{t}-2}$ & $\begin{array}{l}-0.053 \\
(0.059)\end{array}$ & $\begin{array}{l}-0.039 \\
(0.031)\end{array}$ & & \\
\hline$\Delta \log \mathbf{U} C_{i, t-3}$ & $\begin{array}{c}0.010 \\
(0.043)\end{array}$ & $\begin{array}{c}0.029 \\
(0.030)\end{array}$ & & \\
\hline \multirow[t]{2}{*}{$\Sigma_{\mathbf{j}} \Delta \log \mathbf{U} \mathbf{C}_{\mathbf{i}, \mathbf{t}-\mathbf{j}}$} & $\begin{array}{l}-0.586 \\
(0.224)\end{array}$ & $\begin{array}{l}-0.257 \\
(0.117)\end{array}$ & $\begin{array}{l}-0.508 \\
(0.149)\end{array}$ & $\begin{array}{l}-0.225 \\
(0.084)\end{array}$ \\
\hline & \multicolumn{2}{|c|}{$\begin{array}{r}\psi_{\mathbf{u c}}=-0.328 \\
(0.253)\end{array}$} & \multicolumn{2}{|c|}{$\begin{aligned} \psi \mathbf{u c}= & -0.283 \\
& (0.171)\end{aligned}$} \\
\hline \multirow[t]{2}{*}{$\eta_{\mathbf{u c}}$} & $\begin{array}{l}-0.636 \\
(0.246)\end{array}$ & $\begin{array}{l}-0.320 \\
(0.146)\end{array}$ & $\begin{array}{l}-0.564 \\
(0.167)\end{array}$ & $\begin{array}{l}-0.277 \\
(0.104)\end{array}$ \\
\hline & \multicolumn{2}{|c|}{$\begin{aligned} \phi \mathbf{u c}= & -0.316 \\
& (0.286)\end{aligned}$} & \multicolumn{2}{|c|}{$\begin{aligned} \phi \mathbf{u c}= & -0.287 \\
& (0.197)\end{aligned}$} \\
\hline
\end{tabular}


Table 7: GMM Parameter Estimates Of Equation (2)

(cont.) Dependent Variable: $I_{t} / K_{t-1}$

ADL(3) With The First-Difference Estimator

Sub-Samples Defined By Firm Size

\begin{tabular}{|c|c|c|c|c|}
\hline \multirow[b]{2}{*}{ Variable } & \multicolumn{2}{|c|}{ ALL COEFEICIENTS } & \multicolumn{2}{|c|}{ TRIMMED COEFEICIENTS } \\
\hline & $\begin{array}{l}\text { Small } \\
(\mathbf{1})\end{array}$ & $\begin{array}{l}\text { Large } \\
(2)\end{array}$ & $\begin{array}{l}\text { Small } \\
(3)\end{array}$ & $\begin{array}{l}\text { Large } \\
\text { (4) }\end{array}$ \\
\hline$\Delta \log S_{i, t}$ & $\begin{array}{c}0.142 \\
(0.072)\end{array}$ & $\begin{array}{c}0.116 \\
(0.056)\end{array}$ & $\begin{array}{c}0.133 \\
(0.070)\end{array}$ & $\begin{array}{c}0.103 \\
(0.052)\end{array}$ \\
\hline$\Delta \log S_{i, t-1}$ & $\begin{array}{c}0.093 \\
(0.020)\end{array}$ & $\begin{array}{c}0.109 \\
(0.015)\end{array}$ & $\begin{array}{c}0.087 \\
(0.019)\end{array}$ & $\begin{array}{c}0.101 \\
(0.015)\end{array}$ \\
\hline$\Delta \log S_{i, t-2}$ & $\begin{array}{c}0.057 \\
(0.016)\end{array}$ & $\begin{array}{c}0.069 \\
(0.012)\end{array}$ & $\begin{array}{c}0.052 \\
(0.016)\end{array}$ & $\begin{array}{r}0.067 \\
(0.012)\end{array}$ \\
\hline$\Delta \log \mathrm{S}_{\mathrm{i}, \mathrm{t}-3}$ & $\begin{array}{r}0.030 \\
(0.014)\end{array}$ & $\begin{array}{c}0.035 \\
(0.011) \\
\end{array}$ & $\begin{array}{c}0.029 \\
(0.014)\end{array}$ & $\begin{array}{r}0.034 \\
(0.010)\end{array}$ \\
\hline \multirow[t]{2}{*}{$\Sigma_{\mathrm{j}} \Delta \log \mathrm{S}_{\mathrm{i}, \mathrm{t}-\mathrm{j}}$} & $\begin{array}{c}0.323 \\
(0.094)\end{array}$ & $\begin{array}{c}0.329 \\
(0.066)\end{array}$ & $\begin{array}{c}0.301 \\
(0.092)\end{array}$ & $\begin{array}{c}0.305 \\
(0.062)\end{array}$ \\
\hline & \multicolumn{2}{|c|}{$\psi$ s $=\begin{array}{r}-0.007 \\
(0.115)\end{array}$} & \multicolumn{2}{|c|}{$\psi_{\mathrm{s}}=-0.004$} \\
\hline \multirow[t]{2}{*}{$\eta_{\mathrm{s}}$} & $\begin{array}{c}0.350 \\
(0.100)\end{array}$ & $\begin{array}{c}0.409 \\
(0.083) \\
\end{array}$ & $\begin{array}{c}0.334 \\
(0.100)\end{array}$ & $\begin{array}{c}0.375 \\
(0.077) \\
\end{array}$ \\
\hline & \multicolumn{2}{|c|}{$\begin{aligned} \phi_{\mathrm{s}}= & -0.059 \\
& (0.130)\end{aligned}$} & \multicolumn{2}{|c|}{$\begin{aligned} \phi_{\mathrm{s}}= & -0.040 \\
& (0.127)\end{aligned}$} \\
\hline $\mathbf{C F} F_{i, t} / K_{i, t-1}$ & $\begin{array}{c}0.105 \\
(0.041)\end{array}$ & $\begin{array}{c}0.045 \\
(0.029)\end{array}$ & $\begin{array}{c}0.114 \\
(0.027)\end{array}$ & $\begin{array}{c}0.064 \\
(0.025)\end{array}$ \\
\hline $\mathbf{C F}_{\mathrm{i}, \mathrm{t}-1 / \mathrm{K}_{\mathrm{i}, \mathrm{t}-2}}$ & $\begin{array}{c}0.005 \\
(0.016)\end{array}$ & $\begin{array}{c}0.003 \\
(0.012) \\
\end{array}$ & & \\
\hline $\mathbf{C F}_{\mathrm{i}, \mathrm{t}-2} / \mathbf{K}_{\mathrm{i}, \mathrm{t}-\mathbf{3}}$ & $\begin{array}{c}0.002 \\
(0.008)\end{array}$ & $\begin{array}{c}0.008 \\
(0.005)\end{array}$ & & \\
\hline $\mathbf{C F}_{\mathrm{i}, \mathrm{t}-\mathbf{3}} / \mathbf{K}_{\mathrm{i}, \mathrm{t}-\mathbf{4}}$ & $\begin{array}{c}0.006 \\
(0.006)\end{array}$ & $\begin{array}{c}0.005 \\
(0.004)\end{array}$ & & \\
\hline \multirow[t]{2}{*}{$\Sigma_{\mathbf{j}} \mathbf{C F} F_{\mathrm{i}, \mathrm{t}-\mathrm{j}} / \mathbf{K}_{\mathrm{i}, \mathrm{t}-\mathrm{j}-1}$} & $\begin{array}{c}0.119 \\
(0.031) \\
\end{array}$ & $\begin{array}{c}0.061 \\
(0.025) \\
\end{array}$ & $\begin{array}{r}0.114 \\
(0.027)\end{array}$ & $\begin{array}{c}0.064 \\
(0.025)\end{array}$ \\
\hline & \multicolumn{2}{|c|}{$\begin{aligned} \psi_{\mathbf{c f}}= & 0.058 \\
& (0.039)\end{aligned}$} & \multicolumn{2}{|c|}{$\begin{aligned} \psi \mathrm{cf}= & 0.050 \\
& (0.037)\end{aligned}$} \\
\hline \multirow[t]{2}{*}{$\eta_{\mathrm{cf}}$} & $\begin{array}{c}0.129 \\
(0.034)\end{array}$ & $\begin{array}{c}0.076 \\
(0.030)\end{array}$ & $\begin{array}{c}0.126 \\
(0.030)\end{array}$ & $\begin{array}{c}0.078 \\
(0.030)\end{array}$ \\
\hline & \multicolumn{2}{|c|}{$\begin{aligned} \phi_{\mathbf{c f}}= & 0.053 \\
& (0.045)\end{aligned}$} & \multicolumn{2}{|c|}{$\begin{aligned} & \phi_{\mathrm{cf}}= 0.048 \\
&(0.043)\end{aligned}$} \\
\hline
\end{tabular}




\section{Table 7: GMM Parameter Estimates Of Equation (2) (cont.) Dependent Variable: $I_{t} / K_{t-1}$ ADL(3) With The First-Difference Estimator Sub-Samples Defined By Firm Size}

\begin{tabular}{|c|c|c|c|c|}
\hline \multirow[b]{2}{*}{ Variable } & \multicolumn{2}{|c|}{ ALL COEFEICIENTS } & \multicolumn{2}{|c|}{ TRIMMED COEFEICIENTS } \\
\hline & $\begin{array}{c}\text { Small } \\
(1)\end{array}$ & $\begin{array}{c}\text { Large } \\
(2)\end{array}$ & $\begin{array}{l}\text { Small } \\
(3)\end{array}$ & $\begin{array}{l}\text { Large } \\
(4)\end{array}$ \\
\hline $\mathbf{I}_{\mathbf{i}, \mathrm{t}-1} / \mathbf{K}_{\mathrm{i}, \mathrm{t}-1}$ & $\begin{array}{c}0.088 \\
(0.021)\end{array}$ & $\begin{array}{r}0.183 \\
(0.021)\end{array}$ & $\begin{array}{c}0.099 \\
(0.016)\end{array}$ & $\begin{array}{r}0.185 \\
(0.018) \\
\end{array}$ \\
\hline $\mathbf{I}_{\mathrm{i}, \mathrm{t}-2} / \mathbf{K}_{\mathrm{i}, \mathrm{t}-2}$ & $\begin{array}{l}-0.011 \\
(0.011)\end{array}$ & $\begin{array}{c}0.010 \\
(0.012)\end{array}$ & & \\
\hline $\mathbf{I}_{\mathbf{i}, \mathbf{t}-\mathbf{3}} / \mathbf{K}_{\mathbf{i}, \mathbf{t}-\mathbf{3}}$ & $\begin{array}{c}0.002 \\
(0.009)\end{array}$ & $\begin{array}{r}0.001 \\
(0.008) \\
\end{array}$ & & \\
\hline \multirow[t]{2}{*}{$\sum_{\mathbf{j}} \mathbf{I}_{\mathbf{i}, \mathbf{t}-\mathbf{j}} / \mathbf{K}_{\mathbf{i}, \mathbf{t}-\mathbf{j}-\mathbf{1}}$} & $\begin{array}{c}0.078 \\
(0.034)\end{array}$ & $\begin{array}{c}0.195 \\
(0.031)\end{array}$ & $\begin{array}{c}0.099 \\
(0.016)\end{array}$ & $\begin{array}{c}0.185 \\
(0.018)\end{array}$ \\
\hline & \multicolumn{2}{|c|}{$\begin{aligned} \psi \mathrm{IK}= & -0.116 \\
& (0.046)\end{aligned}$} & \multicolumn{2}{|c|}{$\begin{aligned} \psi \mathbf{I K}= & -0.086 \\
& (0.024)\end{aligned}$} \\
\hline SH p-value & \multicolumn{2}{|c|}{0.185} & \multicolumn{2}{|c|}{0.220} \\
\hline LM p-value & \multicolumn{2}{|c|}{0.098} & \multicolumn{2}{|c|}{0.108} \\
\hline Observations & \multicolumn{2}{|c|}{18,713} & \multicolumn{2}{|c|}{18,713} \\
\hline Firms & \multicolumn{2}{|c|}{6,408} & \multicolumn{2}{|c|}{6,408} \\
\hline
\end{tabular}

Notes To Table 7:

See the note to Table 1 for variable definitions. Constants $\left(\zeta_{\mathrm{i}}\right)$ and year dummies $\left(\tau_{\mathrm{t}}\right)$ are also

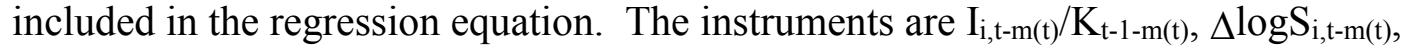

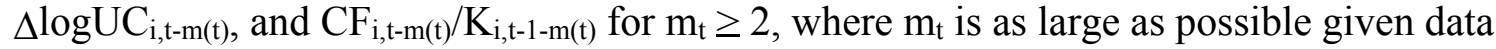
availability and increases over the sample; a constant and $\tau_{\mathrm{t}}$ are also in the instrument set. Heteroscedastic-consistent standard errors are in parentheses. The estimates in column 1 and 2 are sorted by the number of employees: Small are those observations for firms with less than 100 employees; Large is the complementary class. The estimates in column 3 [4] exclude those regressors in column 1 [2] with t-statistics whose $\mathrm{p}$-values are greater than $0.10 . \Sigma_{\mathrm{h}} \mathrm{X}_{\mathrm{i}, \mathrm{t}-\mathrm{h}}$ is the sum of coefficients for variable $\mathrm{X}=\{\mathrm{UC}, \mathrm{S}, \mathrm{CF} / \mathrm{K}, \mathrm{I} / \mathrm{K}\} . \eta \mathrm{X}$ is the long-run elasticity for variable $\mathrm{X}$ (see equation (3) in the text); standard errors are computed by the delta method. $\psi x[\phi x]$ is the difference between the $\left(\Sigma_{\mathrm{j}} \Delta \log \mathrm{X}_{\mathrm{i}, \mathrm{t}-\mathrm{j}}\right)$ 's [ $\eta \mathrm{x}$ 's] for the Small [Large] firms. SH is the p-value for the Sargan-Hansen statistic testing overidentifying restrictions. LM is the $\mathrm{p}$-value for the Lagrange Multiplier statistic testing for second-order autocorrelation. An observation is defined by a "string" of datapoints needed to form a contiguous relation between the dependent and current and lagged independent and lagged dependent variables. Section IV contains a further discussion of these statistics. 
that the German house bank system effectively overcomes the barriers to external finance facing small firms by resolving information problems or lowering transactions costs. These results are consistent with the role of the house bank system described in Elsas and Krahnen (1998) and Worms (2001).

\section{Sorting By The Dividend Payout Ratio}

Sorting by the dividend payout ratio has been a controversial means for identifying credit constrained firms. Fazzari, Hubbard, and Petersen (1988) introduced this sorting in their seminal paper. However, it was criticized by that paper's first reviewer (Blinder, 1988) and, more recently and more severely, by Kaplan and Zingales (1997; cf. fn. 21). Our results in Section VI.A with CWR indicate clearly that a subset of firms in our sample face credit constraints. It thus becomes interesting to examine whether the dividend payout ratio signals credit constraints, as evaluated by the two differential tests.

In Table 8, we sort the sample into those firms that do not pay dividends (Low, constituting about $11 \%$ of the sample) and the complementary class of dividend paying firms (High). ${ }^{23}$ The cash flow coefficient for the non-dividend paying and presumably credit constrained firms equals 0.085 , and is greater than the comparable value of 0.062 for dividend paying firms. However, as assessed by $\psi \mathrm{cf}$, the difference is not statistically significant. A different pattern of results is obtained for the sum of user cost coefficients -- the sum for the Low firms is very close to zero and smaller (in absolute value) than that for the High firms. This result is consistent with the presence of credit constraints and, in contrast to the cash flow coefficients, the difference is statistically significant. ${ }^{24}$ Thus, we get mixed results sorting by the dividend payout ratio. Consistent with Kaplan and Zingales' critique, dividend payout does not reveal a pattern of cash flow coefficients consistent with some firms being credit constrained. However, our test based on the differential sensitivity of user costs is supportive of the credit constraints hypothesis.

\section{Creditworthiness As An Explanatory Variable}

Our final regressions use the CWR variable to measure the external finance premium in a different way. In this sub-section, CWR is a continuous indicator of the markup over the basic user cost as follows,

$$
\mathrm{UC}^{\prime}=\mathrm{UC} *(1-\Gamma * \mathrm{CWR})
$$

\footnotetext{
${ }^{23}$ The dividend payout ratio is calculated as the mean dividend payout for the first three observations before the year in which investment/capital ratio first enters the regression model as a dependent variable divided by the mean cash flow during the same time period. Observations for which mean cash flow was less than or equal to zero are eliminated.

${ }^{24}$ Defining Low by non-dividend paying firms leads to the sharpest distinction between firms. When Low is defined by firm/year observations that are in the lower quartile or below the median, $\psi \mathrm{cf}$ is not different from zero.
} 
Table 8: GMM Parameter Estimates Of Equation (2)

Dependent Variable: $I_{t} / K_{t-1}$

ADL(3) With The First-Difference Estimator

Sub-Samples Defined By Dividend Payout Ratio

\begin{tabular}{|c|c|c|c|c|}
\hline \multirow[b]{2}{*}{ Variable } & \multicolumn{2}{|c|}{ ALL COEFEICIENTS } & \multicolumn{2}{|c|}{ TRIMMED COEFEICIENTS } \\
\hline & $\begin{array}{l}\text { Low } \\
(1)\end{array}$ & $\begin{array}{c}\text { High } \\
(2)\end{array}$ & $\begin{array}{l}\text { Low } \\
\text { (3) }\end{array}$ & $\begin{array}{l}\text { High } \\
\text { (4) }\end{array}$ \\
\hline$\Delta \log \mathrm{UC}_{\mathrm{i}, \mathrm{t}}$ & $\begin{array}{l}-0.059 \\
(0.115)\end{array}$ & $\begin{array}{l}-0.283 \\
(0.084)\end{array}$ & $\begin{array}{c}0.058 \\
(0.099)\end{array}$ & $\begin{array}{l}-0.311 \\
(0.082) \\
\end{array}$ \\
\hline$\Delta \log U C_{i, t-1}$ & $\begin{array}{l}-0.138 \\
(0.077)\end{array}$ & $\begin{array}{l}-0.173 \\
(0.044)\end{array}$ & $\begin{array}{l}-0.054 \\
(0.055)\end{array}$ & $\begin{array}{l}-0.184 \\
(0.035)\end{array}$ \\
\hline$\Delta \log \mathrm{U}_{\mathrm{i}, \mathrm{t}-2}$ & $\begin{array}{l}-0.080 \\
(0.067)\end{array}$ & $\begin{array}{c}-0.028 \\
(0.038) \\
\end{array}$ & & \\
\hline$\Delta \log \mathrm{U}_{\mathrm{i}, \mathrm{t}-\mathrm{3}}$ & $\begin{array}{l}-0.036 \\
(0.055)\end{array}$ & $\begin{array}{c}0.036 \\
(0.030)\end{array}$ & & \\
\hline \multirow[t]{2}{*}{$\Sigma_{\mathbf{j}} \Delta \log \mathbf{U} \mathbf{C}_{\mathrm{i}, \mathrm{t}-\mathrm{j}}$} & $\begin{array}{l}-0.314 \\
(0.239)\end{array}$ & $\begin{array}{l}-0.448 \\
(0.146)\end{array}$ & $\begin{array}{c}0.004 \\
(0.124)\end{array}$ & $\begin{array}{l}-0.496 \\
(0.103)\end{array}$ \\
\hline & \multicolumn{2}{|c|}{$\begin{aligned} \psi & =0.134 \\
& (0.280)\end{aligned}$} & \multicolumn{2}{|c|}{$\psi(\mathbf{u c}=0.500$} \\
\hline \multirow[t]{2}{*}{$\eta_{\text {uc }}$} & $\begin{array}{l}-0.335 \\
(0.255)\end{array}$ & $\begin{array}{l}-0.498 \\
(0.164)\end{array}$ & $\begin{array}{c}0.005 \\
(0.138)\end{array}$ & $\begin{array}{l}-0.570 \\
(0.119)\end{array}$ \\
\hline & \multicolumn{2}{|c|}{$\begin{aligned} \phi \phi_{\mathbf{u c}}= & 0.163 \\
& (0.303)\end{aligned}$} & \multicolumn{2}{|c|}{$\begin{array}{r}\phi_{\mathbf{u c}}=0.574 \\
(0.181)\end{array}$} \\
\hline$\Delta \log S_{i, t}$ & $\begin{array}{c}0.170 \\
(0.056)\end{array}$ & $\begin{array}{c}0.208 \\
(0.060)\end{array}$ & $\begin{array}{c}0.117 \\
(0.048)\end{array}$ & $\begin{array}{c}0.209 \\
(0.057)\end{array}$ \\
\hline$\Delta \log \mathrm{S}_{\mathrm{i}, \mathrm{t}-1}$ & $\begin{array}{c}0.073 \\
(0.029)\end{array}$ & $\begin{array}{c}0.097 \\
(0.017)\end{array}$ & $\begin{array}{c}0.077 \\
(0.027)\end{array}$ & $\begin{array}{c}0.101 \\
(0.016)\end{array}$ \\
\hline$\Delta \log \mathrm{S}_{\mathrm{i}, \mathrm{t}-2}$ & $\begin{array}{c}0.024 \\
(0.026)\end{array}$ & $\begin{array}{c}0.057 \\
(0.014)\end{array}$ & $\begin{array}{c}0.032 \\
(0.024)\end{array}$ & $\begin{array}{c}0.063 \\
(0.013)\end{array}$ \\
\hline$\Delta \log \mathrm{S}_{\mathrm{i}, \mathrm{t}-3}$ & $\begin{array}{c}0.032 \\
(0.020)\end{array}$ & $\begin{array}{c}0.022 \\
(0.011)\end{array}$ & $\begin{array}{c}0.043 \\
(0.019)\end{array}$ & $\begin{array}{c}0.028 \\
(0.011)\end{array}$ \\
\hline \multirow[t]{2}{*}{$\Sigma_{\mathbf{j}} \Delta \log \mathrm{S}_{\mathrm{i}, \mathrm{t}-\mathrm{j}}$} & $\begin{array}{c}0.299 \\
(0.094)\end{array}$ & $\begin{array}{c}0.384 \\
(0.076)\end{array}$ & $\begin{array}{c}0.269 \\
(0.088)\end{array}$ & $\begin{array}{c}0.401 \\
(0.073)\end{array}$ \\
\hline & \multicolumn{2}{|c|}{$\begin{aligned} \psi \mathrm{s}= & -0.085 \\
& (0.121)\end{aligned}$} & \multicolumn{2}{|c|}{$\begin{aligned} \psi s & =-0.132 \\
& (0.113)\end{aligned}$} \\
\hline \multirow[t]{2}{*}{$\eta_{\mathrm{s}}$} & $\begin{array}{c}0.319 \\
(0.099)\end{array}$ & $\begin{array}{c}0.426 \\
(0.084)\end{array}$ & $\begin{array}{c}0.300 \\
(0.098)\end{array}$ & $\begin{array}{c}0.460 \\
(0.084)\end{array}$ \\
\hline & \multicolumn{2}{|c|}{$\begin{aligned} \phi_{\mathrm{s}}= & -0.107 \\
& (0.130)\end{aligned}$} & \multicolumn{2}{|c|}{$\begin{aligned} \phi_{\mathrm{s}}= & -0.161 \\
& (0.127)\end{aligned}$} \\
\hline
\end{tabular}


Table 8: GMM Parameter Estimates Of Equation (2)

(cont.) Dependent Variable: $I_{t} / K_{t-1}$

ADL(3) With The First-Difference Estimator

Sub-Samples Defined By Dividend Payout Ratio

\begin{tabular}{|c|c|c|c|c|}
\hline \multirow[b]{2}{*}{ Variable } & \multicolumn{2}{|c|}{ ALL COEFEICIENTS } & \multicolumn{2}{|c|}{ TRIMMED COEFEICIENTS } \\
\hline & $\begin{array}{l}\text { Low } \\
\text { (1) }\end{array}$ & $\begin{array}{l}\text { High } \\
\text { (2) }\end{array}$ & $\begin{array}{l}\text { Low } \\
\text { (3) }\end{array}$ & $\begin{array}{l}\text { High } \\
\text { (4) }\end{array}$ \\
\hline $\mathbf{C F} F_{i, t} / K_{i, t-1}$ & $\begin{array}{c}0.024 \\
(0.016)\end{array}$ & $\begin{array}{c}0.091 \\
(0.034) \\
\end{array}$ & $\begin{array}{c}0.085 \\
(0.013)\end{array}$ & $\begin{array}{c}0.062 \\
(0.046)\end{array}$ \\
\hline $\mathbf{C F}_{\mathrm{i}, \mathrm{t}-1} / \mathrm{K}_{\mathrm{i}, \mathrm{t}-\mathbf{2}}$ & $\begin{array}{c}0.033 \\
(0.018)\end{array}$ & $\begin{array}{c}0.017 \\
(0.013)\end{array}$ & & \\
\hline $\mathbf{C F} F_{i,-2-2} / K_{i, t-3}$ & $\begin{array}{c}0.047 \\
(0.018)\end{array}$ & $\begin{array}{c}0.012 \\
(0.006) \\
\end{array}$ & & \\
\hline $\mathbf{C F}_{\mathrm{i}, \mathrm{t}-\mathrm{-} / \mathrm{K}_{\mathrm{i}, \mathrm{t}-4}}$ & $\begin{array}{l}-0.004 \\
(0.008)\end{array}$ & $\begin{array}{c}0.010 \\
(0.004)\end{array}$ & & \\
\hline \multirow[t]{2}{*}{$\Sigma_{\mathrm{j}} \mathbf{C} \mathbf{F}_{\mathrm{i}, \mathrm{t}-\mathrm{j}} / \mathbf{K}_{\mathrm{i}, \mathrm{t}-\mathrm{j}-1}$} & $\begin{array}{c}0.100 \\
(0.024)\end{array}$ & $\begin{array}{c}0.131 \\
(0.028)\end{array}$ & $\begin{array}{c}0.085 \\
(0.013)\end{array}$ & $\begin{array}{c}0.062 \\
(0.046)\end{array}$ \\
\hline & \multicolumn{2}{|c|}{$\begin{aligned} \psi(\mathbf{c f}= & -0.031 \\
& (0.037)\end{aligned}$} & \multicolumn{2}{|c|}{$\begin{aligned} \psi \mathbf{c f}= & 0.023 \\
& (0.049)\end{aligned}$} \\
\hline \multirow[t]{2}{*}{$\eta_{\mathrm{cef}}$} & $\begin{array}{c}0.106 \\
(0.025)\end{array}$ & $\begin{array}{c}0.145 \\
(0.031)\end{array}$ & $\begin{array}{c}0.095 \\
(0.014)\end{array}$ & $\begin{array}{c}0.071 \\
(0.052)\end{array}$ \\
\hline & \multicolumn{2}{|c|}{$\begin{aligned} \phi_{\mathrm{cf}}= & -0.039 \\
& (0.040)\end{aligned}$} & \multicolumn{2}{|c|}{$\begin{array}{r}\phi \mathbf{c f}=0.024 \\
(0.056)\end{array}$} \\
\hline $\mathbf{I}_{\mathbf{i}, \mathbf{t}-\mathbf{1}} / \mathbf{K}_{\mathbf{i}, \mathbf{t - 1}}$ & $\begin{array}{c}0.094 \\
(0.026)\end{array}$ & $\begin{array}{c}0.112 \\
(0.017) \\
\end{array}$ & $\begin{array}{c}0.102 \\
(0.023)\end{array}$ & $\begin{array}{c}0.129 \\
(0.014)\end{array}$ \\
\hline $\mathbf{I}_{\mathbf{i}, \mathrm{t}-2 / \mathbf{K}_{\mathrm{i}, \mathrm{t}-\mathbf{2}}}$ & $\begin{array}{l}-0.023 \\
(0.018)\end{array}$ & $\begin{array}{l}-0.007 \\
(0.010) \\
\end{array}$ & & \\
\hline $\mathbf{I}_{\mathbf{i}, \mathbf{t - 3}-\mathbf{K}} / \mathbf{K}_{\mathbf{i}, \mathbf{-}-\mathbf{3}}$ & $\begin{array}{l}-0.010 \\
(0.013)\end{array}$ & $\begin{array}{l}-0.006 \\
(0.007)\end{array}$ & & \\
\hline \multirow[t]{2}{*}{$\Sigma_{\mathbf{j}} \mathbf{I}_{\mathbf{i}, \mathrm{t}-\mathrm{j}} / \mathbf{K}_{\mathrm{i}, \mathrm{t}-\mathrm{j}-\mathbf{1}}$} & $\begin{array}{c}0.061 \\
(0.044)\end{array}$ & $\begin{array}{c}0.099 \\
(0.026)\end{array}$ & $\begin{array}{c}0.102 \\
(0.023)\end{array}$ & $\begin{array}{c}0.129 \\
(0.014)\end{array}$ \\
\hline & \multicolumn{2}{|c|}{$\begin{aligned} \psi \mathbf{I K}= & -0.038 \\
& (0.051)\end{aligned}$} & \multicolumn{2}{|c|}{$\begin{aligned} \psi \mathrm{IIK}= & -0.027 \\
& (0.027)\end{aligned}$} \\
\hline SH p-value & \multicolumn{2}{|c|}{0.071} & \multicolumn{2}{|c|}{0.112} \\
\hline LM p-value & \multicolumn{2}{|c|}{0.201} & \multicolumn{2}{|c|}{0.190} \\
\hline Observations & \multirow{2}{*}{\multicolumn{2}{|c|}{$\begin{array}{l}\frac{15,351}{5,230} \\
5\end{array}$}} & \multicolumn{2}{|c|}{15,351} \\
\hline Firms & & & & \\
\hline
\end{tabular}


Notes To Table 8:

See the note to Table 1 for variable definitions. Constants $\left(\zeta_{\mathrm{i}}\right)$ and year dummies $\left(\tau_{\mathrm{t}}\right)$ are also

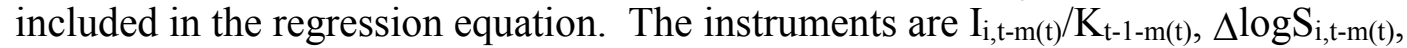

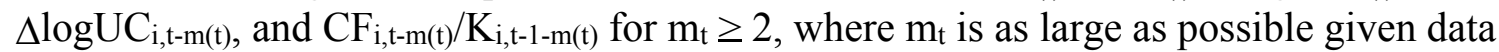
availability and increases over the sample; a constant and $\tau_{\mathrm{t}}$ are also in the instrument set. Heteroscedastic-consistent standard errors are in parentheses. The estimates in column 1 and 2 are sorted by the dividend payout ratio: Low are those observations for firms that did not pay a dividend; High is the complementary class. The estimates in column 3 [4] exclude those regressors in column 1 [2] with t-statistics whose p-values are greater than $0.10 . \Sigma_{h} X_{i, t-h}$ is the sum of coefficients for variable $X=\{\mathrm{UC}, \mathrm{S}, \mathrm{CF} / \mathrm{K}, \mathrm{I} / \mathrm{K}\} . \eta \mathrm{X}$ is the long-run elasticity for variable $\mathrm{X}$ (see equation (3) in the text); standard errors are computed by the delta method. $\psi x[\phi x]$ is the difference between the $\left(\Sigma_{\mathrm{j}} \Delta \log \mathrm{X}_{\mathrm{i}, \mathrm{t}-\mathrm{j}}\right)$ 's [ $\eta \mathrm{x}$ 's] for the Low [High] firms. SH is the $\mathrm{p}$-value for the Sargan-Hansen statistic testing overidentifying restrictions. LM is the p-value for the Lagrange Multiplier statistic testing for second-order autocorrelation. An observation is defined by a "string" of datapoints needed to form a contiguous relation between the dependent and current and lagged independent and lagged dependent variables. Section IV contains a further discussion of these statistics.

where $\Gamma>0$. Since UC enters the model in log differences, we transform (6) accordingly,

$$
\Delta \log \mathrm{UC}^{\prime}=\Delta \log \mathrm{UC}-\Gamma^{*} \Delta \mathrm{CWR}
$$

and enter both terms as regressors. Owing to the timing of the inputs to the ratings undertaken by the Bundesbank, the first value of $\Delta \mathrm{CWR}$ in the regression equation should be lagged one period. Since the user cost enters the model with a negative effect, we would anticipate that $\Delta \mathrm{CWR}$ would have a positive coefficient, indicating that investment increases with the credit rating.

The results in Table 9 confirm the importance of credit constraints via credit ratings on investment. In columns 1 (all coefficients) and 2 (trimmed coefficients), each $\Delta$ CWR coefficient is positive, and the sum is statistically significant. These results may not be fully reflective of the role of $\Delta \mathrm{CWR}$ because it and the cash flow terms may be both capturing the effects of credit constraints. Cash flow variables are excluded from the results reported in columns 3 and 4 , and the sum of $\Delta \mathrm{CWR}$ coefficients rises by $40 \%$ and $139 \%$, respectively. 
Table 9: GMM Parameter Estimates Of Equation (2) With $\triangle \mathbf{C W R}_{\mathbf{t}}$ As An Additional Explanatory Variable Dependent Variable: $I_{t} / K_{t-1}$ ADL(3) With The First-Difference Estimator

\begin{tabular}{|c|c|c|c|c|}
\hline \multirow[b]{2}{*}{ Variable } & \multicolumn{2}{|c|}{ WITH CASHELOW } & \multicolumn{2}{|c|}{ WITHOUT CASHELOW } \\
\hline & $\begin{array}{l}\text { All } \\
\text { (1) }\end{array}$ & $\begin{array}{c}\text { Trimmed } \\
(2)\end{array}$ & $\begin{array}{l}\text { All } \\
(3)\end{array}$ & $\begin{array}{c}\text { Trimmed } \\
(4)\end{array}$ \\
\hline$\Delta \mathbf{C W R}_{\mathrm{t}-1}$ & $\begin{array}{c}0.142 \\
(0.047) \\
\end{array}$ & $\begin{array}{c}0.098 \\
(0.040)\end{array}$ & $\begin{array}{c}0.202 \\
(0.046)\end{array}$ & $\begin{array}{c}0.184 \\
(0.044)\end{array}$ \\
\hline$\Delta \mathbf{C W R}_{\mathrm{t}-2}$ & $\begin{array}{c}0.133 \\
(0.051)\end{array}$ & $\begin{array}{c}0.072 \\
(0.038)\end{array}$ & $\begin{array}{c}0.183 \\
(0.050)\end{array}$ & $\begin{array}{c}0.162 \\
(0.047)\end{array}$ \\
\hline$\Delta \mathbf{C W R}_{\mathrm{t}-3}$ & $\begin{array}{c}0.054 \\
(0.041) \\
\end{array}$ & & $\begin{array}{c}0.076 \\
(0.041) \\
\end{array}$ & $\begin{array}{c}0.061 \\
(0.040)\end{array}$ \\
\hline$\Sigma_{\mathbf{j}} \Delta \mathbf{C} \mathbf{W} \mathbf{R}_{\mathrm{t}-\mathrm{j}}$ & $\begin{array}{c}0.330 \\
(0.118)\end{array}$ & $\begin{array}{c}0.170 \\
(0.071)\end{array}$ & $\begin{array}{c}0.461 \\
(0.118) \\
\end{array}$ & $\begin{array}{c}0.406 \\
(0.111)\end{array}$ \\
\hline$\eta_{\mathrm{cwr}}$ & $\begin{array}{c}0.383 \\
(0.140)\end{array}$ & $\begin{array}{c}0.197 \\
(0.082)\end{array}$ & $\begin{array}{c}0.553 \\
(0.146)\end{array}$ & $\begin{array}{c}0.469 \\
(0.129)\end{array}$ \\
\hline$\Delta \log \mathbf{U} \mathbf{C}_{\mathbf{i}, \mathbf{t}}$ & $\begin{array}{c}-0.182 \\
(0.066)\end{array}$ & $\begin{array}{l}-0.190 \\
(0.065)\end{array}$ & $\begin{array}{l}-0.229 \\
(0.068)\end{array}$ & $\begin{array}{l}-0.221 \\
(0.066)\end{array}$ \\
\hline$\Delta \log \mathrm{UC}_{\mathrm{i}, \mathrm{t}-1}$ & $\begin{array}{l}-0.173 \\
(0.037)\end{array}$ & $\begin{array}{l}-0.161 \\
(0.031)\end{array}$ & $\begin{array}{l}-0.202 \\
(0.037)\end{array}$ & $\begin{array}{l}-0.193 \\
(0.034)\end{array}$ \\
\hline$\Delta \log U C_{i, t-2}$ & $\begin{array}{r}-0.039 \\
(0.032) \\
\end{array}$ & & $\begin{array}{l}-0.062 \\
(0.033)\end{array}$ & $\begin{array}{l}-0.055 \\
(0.028)\end{array}$ \\
\hline$\Delta \log U C_{i, t-3}$ & $\begin{array}{c}0.019 \\
(0.026)\end{array}$ & & $\begin{array}{l}-0.002 \\
(0.027)\end{array}$ & \\
\hline$\Sigma_{\mathbf{j}} \log \mathbf{U} \mathbf{C}_{\mathbf{i}, \mathbf{t}-\mathbf{j}}$ & $\begin{array}{l}-0.375 \\
(0.199)\end{array}$ & $\begin{array}{l}-0.351 \\
(0.084)\end{array}$ & $\begin{array}{l}-0.495 \\
(0.120)\end{array}$ & $\begin{array}{l}-0.470 \\
(0.096)\end{array}$ \\
\hline$\eta$ uc & $\begin{array}{l}-0.436 \\
(0.139) \\
\end{array}$ & $\begin{array}{l}-0.406 \\
(0.098)\end{array}$ & $\begin{array}{l}-0.592 \\
(0.145)\end{array}$ & $\begin{array}{l}-0.542 \\
(0.112)\end{array}$ \\
\hline
\end{tabular}


TABLE 9: GMM Parameter Estimates Of Equation (2) (cont.) With $\triangle \mathbf{C W R}_{\mathbf{t}}$ As An Additional Explanatory Variable Dependent Variable: $I_{t} / K_{t-1}$ ADL(3) With The First-Difference Estimator

\begin{tabular}{|c|c|c|c|c|}
\hline \multirow[b]{2}{*}{ Variable } & \multicolumn{2}{|c|}{ WITH CASHELOW } & \multicolumn{2}{|c|}{ WITHOUT CASHELOW } \\
\hline & (1) All & Trimmec & ${ }_{(3)}{ }^{A l}$ & $\begin{array}{l}\text { Trimmed } \\
\text { (4) }\end{array}$ \\
\hline$\Delta \log S_{i, t}$ & $\begin{array}{c}0.110 \\
(0.049) \\
\end{array}$ & $\begin{array}{c}0.112 \\
(0.047) \\
\end{array}$ & $\begin{array}{c}0.149 \\
(0.049)\end{array}$ & $\begin{array}{c}0.153 \\
(0.049)\end{array}$ \\
\hline$\Delta \log S_{i, t-1}$ & $\begin{array}{c}0.085 \\
(0.014)\end{array}$ & $\begin{array}{c}0.083 \\
(0.014)\end{array}$ & $\begin{array}{c}0.097 \\
(0.013)\end{array}$ & $\begin{array}{c}0.099 \\
(0.013)\end{array}$ \\
\hline$\Delta \log S_{i, t-2}$ & $\begin{array}{c}0.054 \\
(0.012)\end{array}$ & $\begin{array}{c}0.055 \\
(0.011)\end{array}$ & $\begin{array}{c}0.062 \\
(0.011)\end{array}$ & $\begin{array}{c}0.066 \\
(0.011)\end{array}$ \\
\hline$\Delta \log S_{i, t-3}$ & $\begin{array}{c}0.026 \\
(0.010) \\
\end{array}$ & $\begin{array}{c}0.033 \\
(0.009) \\
\end{array}$ & $\begin{array}{c}0.033 \\
(0.010) \\
\end{array}$ & $\begin{array}{c}0.037 \\
(0.010) \\
\end{array}$ \\
\hline$\Sigma_{\mathbf{j}} \Delta \log \mathbf{S}_{\mathrm{i}, \mathrm{t}-\mathrm{j}}$ & $\begin{array}{c}0.275 \\
(0.063)\end{array}$ & $\begin{array}{c}0.283 \\
(0.059)\end{array}$ & $\begin{array}{c}0.341 \\
(0.060)\end{array}$ & $\begin{array}{c}0.355 \\
(0.059)\end{array}$ \\
\hline$\eta_{\mathrm{s}}$ & $\begin{array}{c}0.319 \\
(0.071)\end{array}$ & $\begin{array}{c}0.327 \\
(0.067)\end{array}$ & $\begin{array}{c}0.410 \\
(0.071)\end{array}$ & $\begin{array}{c}0.410 \\
(0.068)\end{array}$ \\
\hline $\mathbf{C F}_{\mathrm{i}, \mathrm{t}} / \mathrm{K}_{\mathrm{i}, \mathrm{t}-\mathbf{1}}$ & $\begin{array}{c}0.057 \\
(0.031)\end{array}$ & $\begin{array}{c}0.083 \\
(0.023) \\
\end{array}$ & & \\
\hline $\mathbf{C F}_{\mathrm{i}, \mathrm{t}-1} / \mathrm{K}_{\mathrm{i}, \mathrm{t}-2}$ & $\begin{array}{c}0.011 \\
(0.013) \\
\end{array}$ & & & \\
\hline $\mathbf{C F}_{\mathrm{i}, \mathrm{t}-2} / \mathrm{K}_{\mathrm{i}, \mathrm{t}-\mathbf{3}}$ & $\begin{array}{c}0.005 \\
(0.005) \\
\end{array}$ & & & \\
\hline $\mathbf{C F}_{\mathrm{i}, \mathrm{t}-\mathrm{3}} / \mathrm{K}_{\mathrm{i}, \mathrm{t}-\mathbf{4}}$ & $\begin{array}{c}0.006 \\
(0.004)\end{array}$ & & & \\
\hline$\Sigma_{\mathbf{j}} \mathbf{C} \mathbf{F}_{\mathrm{i}, \mathrm{t}-\mathrm{j}} / \mathbf{K}_{\mathrm{i}, \mathrm{t}-\mathrm{j}-\mathbf{1}}$ & $\begin{array}{c}0.079 \\
(0.023)\end{array}$ & $\begin{array}{c}0.083 \\
(0.023)\end{array}$ & & \\
\hline$\eta_{\mathbf{c f}}$ & $\begin{array}{c}0.092 \\
(0.027) \\
\end{array}$ & $\begin{array}{c}0.095 \\
(0.027)\end{array}$ & & \\
\hline $\mathbf{I}_{\mathbf{i}, \mathbf{t}-1} / \mathbf{K}_{\mathrm{i}, \mathrm{t}-\mathbf{1}}$ & $\begin{array}{c}0.130 \\
(0.016) \\
\end{array}$ & $\begin{array}{c}0.134 \\
(0.013) \\
\end{array}$ & $\begin{array}{c}0.144 \\
(0.016) \\
\end{array}$ & $\begin{array}{c}0.134 \\
(0.014)\end{array}$ \\
\hline $\mathbf{I}_{\mathbf{i}, \mathbf{t}-2} / \mathbf{K}_{\mathbf{i}, \mathbf{t - 2}}$ & $\begin{array}{c}0.002 \\
(0.009)\end{array}$ & & $\begin{array}{c}0.010 \\
(0.009)\end{array}$ & \\
\hline $\mathbf{I}_{\mathrm{i}, \mathrm{t}-\mathbf{3}} / \mathbf{K}_{\mathbf{i}, \mathbf{t - 3}}$ & $\begin{array}{c}0.007 \\
(0.007) \\
\end{array}$ & & $\begin{array}{c}0.012 \\
(0.007)\end{array}$ & \\
\hline$\Sigma_{\mathbf{j}} \mathbf{I}_{\mathbf{i}, \mathrm{t}-\mathrm{j}} / \mathbf{K}_{\mathrm{i}, \mathrm{t}-\mathrm{j}-\mathbf{1}}$ & $\begin{array}{c}0.139 \\
(0.025)\end{array}$ & $\begin{array}{c}0.134 \\
(0.013)\end{array}$ & $\begin{array}{c}0.166 \\
(0.025)\end{array}$ & $\begin{array}{c}0.134 \\
(0.014)\end{array}$ \\
\hline SH p-value & 0.063 & 0.056 & 0.040 & 0.036 \\
\hline LM p-value & 0.181 & 0.168 & 0.257 & 0.272 \\
\hline Observations & 18,713 & 18,713 & 18,713 & 18,713 \\
\hline Firms & 6,408 & 6,408 & 6,408 & 6,408 \\
\hline
\end{tabular}


Notes To Table 9:

See the note to Table 1 for variable definitions, and Section IV.D for the specification of $\Delta C W R_{t-h}$ as regressors. Constants $\left(\zeta_{\mathrm{i}}\right)$ and year dummies $\left(\tau_{t}\right)$ are also included in the regression equation.

The instruments are $\mathrm{I}_{\mathrm{i}, \mathrm{t}-\mathrm{m}(\mathrm{t})} / \mathrm{K}_{\mathrm{t}-1-\mathrm{m}(\mathrm{t})}, \Delta \log \mathrm{S}_{\mathrm{i}, \mathrm{t}-\mathrm{m}(\mathrm{t})}, \Delta \log \mathrm{UC}_{\mathrm{i}, \mathrm{t}-\mathrm{m}(\mathrm{t})}$,

$\mathrm{CF}_{\mathrm{i}, \mathrm{t}-\mathrm{m}(\mathrm{t})} / \mathrm{K}_{\mathrm{i}, \mathrm{t}-1-\mathrm{m}(\mathrm{t})}$, and $\Delta \mathrm{CWR}_{\mathrm{t}-\mathrm{m}}$ for $\mathrm{m}_{\mathrm{t}} \geq 2$, where $\mathrm{m}_{\mathrm{t}}$ is as large as possible given data availability and increases over the sample; a constant and $\tau_{\mathrm{t}}$ are also in the instrument set. Heteroscedasticconsistent standard errors are in parentheses. Column 1 is based on the ADL(3) with all lag coefficients, and includes lags of $\triangle \mathrm{CWR}$ as regressors. Column 3 is similar to the model in column 1 , but cexcludes the $\mathrm{CF} / \mathrm{K}$ regressors. Column 2 [4] excludes those regressors in column 1 [3] with $\mathrm{t}$-statistics whose $\mathrm{p}$-values are greater than $0.10 . \Sigma_{\mathrm{h}} \mathrm{X}_{\mathrm{i}, \mathrm{t}-\mathrm{h}}$ is the sum of coefficients for variable $\mathrm{X}=\{\mathrm{UC}, \mathrm{S}, \mathrm{CF} / \mathrm{K}, \mathrm{I} / \mathrm{K}\} . \eta \mathrm{X}$ is the long-run elasticity for variable $\mathrm{X}$ (see equation (3) in the text); standard errors are computed by the delta method. SH is the p-value for the Sargan-Hansen statistic testing overidentifying restrictions. LM is the p-value for the Lagrange Multiplier statistic testing for second-order autocorrelation. An observation is defined by a "string" of datapoints needed to form a contiguous relation between the dependent and current and lagged independent and lagged dependent variables. Section IV contains a further discussion of these statistics.

\section{Conclusions}

This paper examines the monetary transmission mechanism in Germany as it affects business fixed investment with an extremely rich dataset containing financial statement, user cost, and creditworthiness data for 6,408 firms (44,345 datapoints). We document that both interest rate and credit channels are important in Germany.

While any set of empirical results must be interpreted with due caution, we nonetheless believe that three important policy conclusions follow from this study. First, we obtain a statistically and economically significant price sensitivity of investment spending. Our computations suggest that a 100 basis point decrease in nominal interest rates (without offsetting changes in inflation expectations) over two years can lead to an increase of investment spending of $7.55 \%$ and GDP of approximately $1.40 \%$ during the same period. Thus, the interest rate channel of monetary policy can be quite potent in Germany.

Second, the differential responses to cash flow and user cost documented here suggests that changes in interest rates engineered by the central bank alter the external finance premium and have differential impacts across firms. Consequently, the weakest firms may be the hardest hit during a monetary contraction, and policymakers need to look beyond broad aggregates to understand the effects of monetary policy.

Third, a continuing decline in the role of the German house bank system may affect the transmission mechanism. No differential responses are uncovered when firms were sorted by size. This result suggests that, over our sample, the German house bank system effectively overcomes barriers to external finance facing small firms by resolving information problems or lowering transactions costs. If this central element of the German financial system is supplanted by market based 
mechanisms for allocating credit, the monetary transmission mechanism will likely be altered.

Whether the channels identified in this study are sufficiently strong to explain the aggregate effects of interest rate changes on business investment remains an open question. To undertake such an evaluation, we must account for the dynamic feedbacks among interest rates, investment spending, and cash flows. Given the differential effects across firms found in this study, these dynamic feedbacks need to be modeled at the firm-level, a task that we hope to pursue in future work.

\section{Acknowledgement}

For helpful comments, we thank Steve Bond, Nick Bloom, Jean-Bernard Chatelain, Andrea Generale, Ignacio Hernando, Heinz Herrmann, Amir Kia, Andy Meyer, Philip Vermeulen, Andy Young, and participants in seminars at the Bundesbank, the Institute For Fiscal Studies, Emory University and in meetings of the Monetary Transmission Network within the European System Of Central Banks. We also acknowledge the invaluable contribution of Fred Ramb with respect to the construction of our user cost variable. The views expressed in this paper do not necessarily reflect those of the Deutsche Bundesbank or CESifo. All errors, omissions, and conclusions remain the sole responsibility of the authors.

\section{References}

Abel, Andrew B., and Eberly, Janice C., "A Unified Model Of Investment Under Uncertainty," American Economic Review 84 (December 1994), 1369-1384.

Arellano, Manuel, and Bond, Stephen, "Some Tests Of Specifications For Panel Data: Monte Carlo Evidence And An Application to Employment Equations," The Review of Economic Studies 58 (April 1991), 277-298.

Arellano, Manuel and, Bover, Olympia, "Another Look At The Instrumental-Variable Estimation Of Error-Components Models," Journal of Econometrics 68 (July 1995), 29-51.

Auerbach, Alan J., "Taxation, Corporate Financial Policy And The Cost Of Capital," Journal of Economic Literature 21 (1983), 905-940.

Barnett, Steven A., and Sakellaris, Plutarchos, "Nonlinear Response Of Firm Investment To Q: Testing A Model Of Convex And Non-Convex Adjust-ment Costs," Journal Of Monetary Economics 42 (October 1998), 261-288.

Bernanke, Benjamin S., and Blinder Alan S., "The Federal Funds Rate And The Channels Of Monetary Transmission," American Economic Review 82 (September 1992), 901-921. 
Bernanke, Ben, and Gertler, Mark, "Financial Fragility And Economic Performance," The Quarterly Journal Of Economics 105 (February 1990, $87-114$.

Bernanke, Ben, Gertler, Mark, Gilchrist, Simon, "The Financial Accelerator And The Flight To Quality," The Review Of Economics And Statistics 78 (February 1996), 1-15.

Blanchard, Olivier J., "Why Does Money Affect Output?: A Survey," in Benjamin Friedman and Frank H. Hahn (eds.), Handbook Of Monetary Economics, Volume 2 (Amsterdam: Elsevier North-Holland, 1990), 779-835.

Blinder, Alan S., "Comment: 'Financing Constraints And Corporate Investment,"' Brookings Papers on Economic Activity 1988:1, 196-200.

Blundell, Richard, and Bond, Stephen, "Initial Conditions And Moment Restrictions In Dynamic Panel Data Models," Journal Of Econometrics 87 (1998). 115-144.

Bond, Stephen, Elston, Julie, Mairesse, Jacques, Mulkay, BenoTt, "Financial Factors And Investment In Belgium, France, Germany, and the UK: A Comparison Using Company Panel Data," Oxford And The Institute For Fiscal Studies (December 2001).

Caballero, Ricardo J., "Aggregate Investment," in John B. Taylor and Michael Woodford (eds.), Handbook Of Macroeconomics, Volume 1B (Amsterdam: Elsevier North-Holland), 1999), 813-862.

Chenells, Lucy, and Griffith, Rachel, Taxing Profits In A Changing World (London: The Institute for Fiscal Studies, 1997).

Chirinko, Robert S., "Business Tax Policy, The Lucas Critique, And Lessons from the 1980s," American Economic Review 78 (May 1988), 206-210.

Chirinko, Robert S, "Business Fixed Investment: A Critical Survey Of Modeling Strategies, Empirical Results, And Policy Implications," Journal of Economic Literature 31 (December 1993a), 1875-1911.

Chirinko, Robert S., Econometric Models And Empirical Findings For Business Investment (New York: Basil Blackwell, 1993b). (A Monograph in the Salomon Brothers Center Series Financial Markets, Institutions \& Instruments.)

Chirinko, Robert S., Fazzari, Steven M., and Meyer, Andrew P., "How Responsive Is Business Capital Formation To Its User Cost?: An Exploration With Micro Data," Journal of Public Economics 74 (October 1999), 53-80.

Christiano, Lawrence J., Eichenbaum, Martin, Evans, Charles L., "The Effects Of Monetary Policy Shocks: Evidence From The Flow Of Funds," Review Of Economics And Statistics 78 (1996), 16-34. 
Christiano, Lawrence J., Eichenbaum, Martin, Evans, Charles L., "Monetary Policy Shocks: What Have We Learned And To What End?," in John B. Taylor and Michael Woodford (eds.), Handbook Of Macroeconomics, Volume 1A (Amsterdam: Elsevier North-Holland), 1999), 65-148.

Coen, Robert M., "Tax Policy And Investment Behavior: Comment," American Economic Review 59 (June 1969), 370-379.

Deutsche Bundesbank, "The Methodological Basis Of The Deutsche Bundesbank's Corporate Balance Sheet Statistics," Deutsche Bundesbank Monthly Report 50 (October 1998), 4964.

Deutsche Bundesbank, "The Bundesbank's Method Of Assessing The Creditworthiness Of Business Enterprises," Deutsche Bundesbank Monthly Report 50 (January 1999), 51-63.

Dixit, Avinash K., and Pindyck, Robert S., Investment Under Uncertainty (Princeton: Princeton University Press, 1994).

Eisner, Robert, and Nadiri, M. Ishaq, "Investment Behavior And Neo-Classical Theory," The Review of Economics and Statistics 50 (August 1968), 369-382.

Eisner, Robert, and Nadiri, M. Ishaq, "Neoclassical Theory Of Investment Behavior: A Comment," The Review of Economics and Statistics 52 (May 1970), 216-222.

Elsas, R., and Krahnen, Jan P., "Is Relationship-Lending Special? Evidence From CreditFile Data In Germany,” Journal Of Banking And Finance 22 (1998), 1283-1316.

Erickson, Timothy, and Whited, Toni M., "Measurement Error And The Relationship Between Investment And q," Journal Of Political Economy 108 (October 2000), 1027-1057.

Fazzari, Steven M., Hubbard, R. Glenn, and Petersen, Bruce C., "Financing Constraints And Corporate Investment," Brookings Papers on Economic Activity (1988:1), 141-195.

Fazzari, Steven M., Hubbard, R. Glenn, and Petersen, Bruce C., "Investment-Cash Flow Sensitivities Are Useful: A Comment On Kaplan and Zingales," Quarterly Journal of Economics 115 (May 2000), 695-705.

Friedman, Milton, and Schwartz, Anna J., A Monetary History Of The United States 18671960 (Princeton: Princeton University Press (for the NBER), 1963).

Greenspan, Alan, "Greenspan Says Fed's Rate Cuts Are Working," New York Times (July 25, 2001), Section C, page 6.

Hall, Robert E., and Jorgenson, Dale W., "Tax Policy And Investment Behavior," American Economic Review 57 (June 1967), 391-414.

Hall, Robert E., and Jorgenson, Dale W., "Tax Policy And Investment Behavior: Reply And Further Results," American Economic Review 59 (June 1969), 388-401. 
Hansen, Lars Peter, "Large Sample Properties Of Generalized Method Of Moments Estimators," Econometrica 50 (July 1982), 1029-1054.

Harhoff, Dietmar, and Ramb, Fred, "Investment And Taxation: Evidence From Firm-Level Panel Data," in Deutsche Bundesbank (ed.), Investing Today For The World Of Tomorrow: Studies On The Investment Process In Europe (Berlin: Springer-Verlag, 2001), 47-73.

Hassett, Kevin A., and Hubbard, R. Glenn, "Tax Policy And Investment," in Alan J. Auerbach, ed., Fiscal Policy: Lessons from Economic Research (Cambridge: MIT Press, 1997), 339-385.

Hubbard, R. Glenn, "Capital-Market Imperfections And Investment," Journal of Economic Literature 36 (March 1998), 193-225.

Jorgenson, Dale W., "Capital Theory And Investment Behavior," American Economic Review 53 (May 1963), 247-259.

Jorgenson, Dale W., "Rational Distributed Lag Functions," Econometrica 34 (January 1966), 135-149.

Jorgenson, Dale W., and Stephenson, James A., "The Time Structure Of Investment Behavior In U.S. Manufacturing, 1947-1960," The Review of Economics and Statistics 49 (February 1967), 16-27.

Jorgenson, Dale W., and Stephenson, James A., "Issues In The Development Of The Neoclassical Theory Of Investment Behavior," The Review of Economics and Statistics 51 (August 1969), 346-353.

von Kalckreuth, Ulf, "Exploring The Role Of Uncertainty For Corporate Investment Decisions In Germany," Economic Research Group Of The Deutsche Bundesbank Discussion Paper 5/00 (September 2000).

Kaplan, Steven N., and Zingales, Luigi, "Do Investment-Cash Flow Sensitivities Provide Useful Measures Of Finance Constraints?," Quarterly Journal Of Economics 112 (February 1997), 169-215.

Kaplan, Steven N., and Zingales, Luigi, "Investment-Cash Flow Sensitivities Are Not Valid Measures Of Financing Constraints," Quarterly Journal Of Economics 115 (May 2000), 707-712.

King, Mervyn A., and Fullerton, Don (eds.), The Taxation of Income from Capital (Chicago: University of Chicago Press (for the NBER), 1984).

Mishkin, Frederic S., "Symposium On The Monetary Transmission Mechanism,” Journal Of Economic Perspectives 9 (Fall 1995), 3-96.

OECD, Taxing Profits In A Global Economy. Domestic and International Issues (Paris: OECD, 1991). 
Oliner, Stephen D., and Rudebusch, Glenn D., "Sources Of The Financing Hierarchy For Business Investment," The Review Of Economics And Statistics 74 (November 1992), 643-654.

Ramb, Fred, Steuersystem und Investitionstaetigkeit. Eine Panelokoekonometrische Untersuchung fuer Deutschland (Taxation And Investment: A Panel Econometric Investigation For Germany) (Baden-Baden: Nomos Verlag, 2003).

Romer, Christina D., and Romer, David H., "Does Monetary Policy Matter? A New Test In The Spirit Of Friedman and Schwartz," NBER Macroeconomic Annual 1989 (Cambridge: MIT Press, 1989), 121-170.

Rudebusch, Glenn D., "Assessing The Lucas Critique In Monetary Policy Models," Federal Reserve Bank Of San Francisco (February 2002).

Sargan, John D., "The Estimation Of Economic Relationships Using Instrumental Variables," Econometrica 26 (1958), 393-415.

Schiantarelli, Fabio, "Financial Constraints And Investment: A Critical Review Of Methodological Issues And International Evidence," in Joe Peek and Eric S. Rosengren (eds.), Is Bank Lending Important For The Transmission Of Monetary Policy? (Boston: Federal Reserve Bank Of Boston, 1995), 177-214.

Sinn, Hans-Werner, "Systeme Der Kapitaleinkommensbesteuerung: Ein Allokationstheorethischer Vergleich" "'Systems of Capital Income Taxation: A Comparison With Respect To Allocation"), in Dieter Boes, Manfred Rose, and Christian Seidl (eds.), Beitraege Zur Neueren Steuertheorie: Referate Des Finanztheoretischen Seminars Im Kloster Neustift Bei Brixen 1983 (Berlin: Springer, 1984), 209-238.

Sinn, Hans-Werner, Capital Income Taxation And Resource Allocation (Amsterdam: NorthHolland, 1987). (Published in German as Kapitalein-kommensbesteuerung (Tuebingen: Mohr, 1985).)

Stiglitz, Joseph E., and Weiss, Andrew, "Credit Rationing In Markets With Imperfect Information," American Economic Review 71 (June 1981), 393-410.

Stoess, Elmar, "Deutsche Bundesbank's Corporate Balance Sheet Statistics And Areas of Application," Schmollers Jahrbuch: Zeitschrift fuer Wirtschafts- und Sozialwissenschaften (Journal of Applied Social Science Studies) 121 (Spring 2001), 131-137.

Taylor, John B., "Monetary Policy And The Stability Of Macroeconomic Relationships," Journal of Applied Econometrics 4 (December 1989), S161-S178.

Taylor, John B., "The Monetary Transmission Framework: An Empirical Framework," Journal Of Economic Perspectives 9 (Fall 1995), 11-26. 
Williamson, Stephen D., "Costly Monitoring, Loan Contracts, And Equilibrium Credit Rationing," Quarterly Journal Of Economics 102 (February 1987), 135-146.

Worms, Andreas, "Monetary Policy Effects On Bank Loans In Germany: A PanelEconometric Analysis," Deutsche Bundesbank Discussion Paper 17/01 (December 2001).

\section{Appendix A \\ The Construction Of User Costs Of Capital For Germany ${ }^{25}$}

The Jorgensonian user cost of capital (see Auerbach (1983) for a derivation) is given by the following formula,

$$
U C=\frac{p^{I}}{p} \frac{(1-A)\left(\rho-\pi^{I}+\delta^{e}\right)}{(1-\tau)},
$$

where $p$ is the output price level, $p^{\mathrm{I}}$ is the price of investment goods, $A$ is the present value of depreciation allowances, $\rho$ is the nominal discount rate, $\pi^{\mathrm{I}}$ is the expected rate of investment goods price inflation, $\delta$ is the economic depreciation rate, and $\tau$ is the basic corporate tax rate (the rate of tax paid if no profits are distributed). The user cost formula usually reflects investment tax credits determined as a percentage of the price of a purchased asset. During our sample period, no such credits were granted to German firms.

Our construction of user costs takes into account multiple assets, multiple sources of funds, and individual taxation following the approach developed by King and Fullerton (1984), extended by the OECD (1991) and Chenells and Griffith (1997), and applied to the German data by Harhoff and Ramb (2001) and Ramb (2003).

If we distinguish as sources of finance between debt finance, new share issues, and retained earnings, the respective discount rates are given by

$$
\rho= \begin{cases}i \cdot(1-\tau) & \text { for debt } \\ i / \theta & \text { for new shares } \\ i \cdot \frac{1-m}{1-z} & \text { for retained earnings }\end{cases}
$$

\footnotetext{
${ }^{25}$ The user cost of capital for our sample have been constructed on the basis of the computer routines provided by Fred Ramb, who also allowed us to use his tax and depreciation data. Fred's help was crucial and decisive. As we made several changes, however, we have to bear responsibility for the user costs used in this study.
} 
In this expression, the variable $\theta$ measures the degree of discrimination between retentions and distributions. It is the opportunity costs of retained earnings in terms of gross dividends forgone; $\theta$ equals the additional dividend shareholders would receive if one unit of post-corporate tax earnings were distributed. Furthermore, $i$ is the nominal interest rate, $\mathrm{m}$ is the marginal personal tax rate on capital income, and $\mathrm{z}$ is the effective tax rate on accrued capital gains.

Between 1977 and 2000, the system of capital income taxation operating in Germany was a split rate system with full imputation. Shareholders who were residents of the Federal Republic received a tax credit in the amount of the corporation tax on distributed profits paid. Ultimately, the tax on capital income on distributed profits was equal to the marginal tax on capital income. For Germany, therefore, the variable $\theta$ assumes the value $1 /(1-\tau)$. Furthermore, the effective tax rate on accrued capital gains was zero, as capital gains were not taxed after a holding period of one year or more. In this case, the expression for the discount rate reduces to

$$
\rho= \begin{cases}i \cdot(1-\tau) & \text { for debt } \\ i \cdot(1-\tau) & \text { for new shares } \\ i \cdot(1-m) & \text { for retained earnings }\end{cases}
$$

In the system with full imputation that prevailed in Germany from 1977 to 2000, the two types of outside finance are equivalent (Sinn, 1984 and 1987).

To implement this framework and quantify (A-1), we use sector-specific output price levels $\left(\mathrm{p}_{\mathrm{j}, \mathrm{t}}\right)$ and depreciation rate $\left(\delta_{\mathrm{j}, \mathrm{t}}^{\mathrm{e}}\right)$, where $\mathrm{j}$ indexes sectors. Depreciation rates are calculated from a perpetual inventory equation for sectoral capital stocks and investment flows; rates for 1995-1997 are imputed. The price of capital goods $\left(\mathrm{p}_{\mathrm{t}}^{\mathrm{I}}\right)$ is an economy-wide deflator dated at the beginning of the year, and the expected inflation rate $\left(\pi_{t}{ }^{\mathrm{I}}\right)$ measures the rate of growth of $\mathrm{p}_{t}^{\mathrm{I}}$ between the beginning and the end of year $t . A_{a, t}$ is the present value of depreciation allowances as a firm-specific asset-weighted average for three different types of assets (indexed by a): building, machinery and equipment. In each case, finance-specific discount rates are used. ( $\mathrm{A}_{\mathrm{a}, \mathrm{t}}$ is computed with an optimal switch from accelerated to straightline depreciation methods.) The rate of interest rate $\left(i_{t}\right)$ is the average yield to maturity of domestic listed debt securities. The tax rate on retained earnings is calculated as a compound tax combining three different taxes of profits: the basic corporate tax on retained earnings $\left(\tau_{\mathrm{t}}^{\mathrm{r}}\right)$, the local tax (Gewerbesteuer, $\mathrm{g}_{\mathrm{t}}$, is deductible for corporate tax purposes), and the "solidarity surcharge" ( $\mathrm{s}_{\mathrm{t}}$, which is levied on all corporate and personal tax payments), 


$$
\tau_{t}=\left(1+s_{t}\right) \tau_{t}^{r}\left(1-g_{t}\right)+g_{t}
$$

As in King and Fullerton, we treat local taxes as a normal tax on profits, ignoring some of its special features. ${ }^{26}$ As a marginal tax rate for the shareholder, we used the highest marginal income tax $m_{t}^{\max }$, again inflated by the solidarity surcharge,

$$
m_{t}=\left(1+s_{t}\right) m_{t}^{\max } .
$$

To combine the different user costs resulting from the three different sources of finance, we use a flow weights defined for the three sources of finance as follows: debt (with total liabilities including the share of borrowed funds in the reserve subject to future taxation), new shares (the first difference of the stock of subscribed capital augmented by share premium or paid-in surplus), and retained earnings (retained earnings with the earned surplus including the share of own funds in the reserves subject to future taxation). For increases of debt, new shares, or retained earnings, the corresponding weight is calculated as a ratio to the sum of positive sources of new finance in that year. If a particular weight assumes a negative value, it is set to zero for that year; in each year, the weights sum to unity. For the first year, the respective stock weights are used.

\section{Appendix B}

\section{Derivation Of The Autoregressive Distributed Lag (ADL) Model}

This appendix contains a derivation of the ADL model that is the basis for the estimates presented in this study. The ADL takes as its starting point the demand for the desired capital stock,

$$
\mathrm{k}^{*}{ }_{\mathrm{t}}=\sigma \mathrm{uc}^{*}+\xi \mathrm{s}_{\mathrm{t}}{ }_{\mathrm{t}}
$$

where $\mathrm{k}_{\mathrm{t}}$ is the $\log$ of the desired (or long-run) stock of capital, $\mathrm{s}_{\mathrm{t}}$ is the $\log$ of desired output measured by sales, $\mathrm{uc}^{*}{ }_{\mathrm{t}}$ is the $\log$ of the long-run user cost, $\xi$ and $\sigma$ are long-run elasticities representing the technology, and the $t$ subscript indexes time. For expositional simplicity, we do not include firm-specific subscripts in this derivation. Equation (B-1) follows from a CES production function containing capital and any number of additional factors of production. Note that $\sigma$ is the

\footnotetext{
${ }^{26}$ Interest payments are only partly deductible, and the Gewerbesteuer payments are not credited to the shareholders on distribution. The latter, strictly speaking, destroys the basic equivalence between sources of outside finance. The Gewerbesteuer is raised at the local level. Due to data limitations, however, we have to confine ourselves to the mean Gewerbesteuer rate for the whole sample.
} 
elasticity of substitution between labor and capital, and is a key parameter in determining the strength of the interest rate channel of monetary policy on capital formation.

The challenge facing the applied econometrician is to translate the above demand for a stock of capital into the demand for the flow of investment. We begin this translation by assuming that investment equals the change in the desired capital stock,

$$
\Delta \mathrm{k}_{\mathrm{t}}=\Delta \mathrm{k}^{*},
$$

where $\Delta$ is the first difference operator and $\mathrm{k}_{\mathrm{t}}$ is the $\log$ of the capital stock.

Equation (B-2) is not a satisfactory investment equation because it assumes that the actual capital stock adjusts instantaneously to changes in the desired capital stock. Furthermore, $\mathrm{k}^{*}{ }_{\mathrm{t}}$ is unobservable. To derive a useful econometric specification, we introduce dynamics with three assumptions. First, we assume that the adjustment of the actual capital stock (or the investment-capital ratio less depreciation) to its desired level is distributed over time according to the following distributed lag,

$$
\Delta \mathrm{k}_{\mathrm{t}}=\mathrm{I}_{\mathrm{t}} / \mathrm{K}_{\mathrm{t}-1}-\delta=\mathrm{a}(\mathrm{L}) \Delta \mathrm{k}^{*} \text {, }
$$

where $\mathrm{a}(\mathrm{L})$ is a polynomial in the lag operator representing technological constraints such as delivery lags and other adjustment frictions.

Second, following Jorgenson (1966), we assume that a(L) can be approximated by a rational lag, $b(\mathrm{~L}) /(1-\mathrm{c}(\mathrm{L}))$, and rewrite (A-3) as follows,

$$
\begin{aligned}
\mathrm{I}_{\mathrm{t}} / \mathrm{K}_{\mathrm{t}-1}-\delta & =\mathrm{b}(\mathrm{L}) /(1-\mathrm{c}(\mathrm{L})) \Delta \mathrm{k}^{*}{ }_{\mathrm{t}} \\
& =\zeta+\mathrm{b}(\mathrm{L}) \Delta \mathrm{k}^{*}{ }_{\mathrm{t}}+\mathrm{c}(\mathrm{L}) \mathrm{I}_{\mathrm{t}-1} / \mathrm{K}_{\mathrm{t}-2},
\end{aligned}
$$

where $\zeta=\delta(1-\mathrm{c}(1))$. The $\mathrm{b}(\mathrm{L})$ 's, $\mathrm{c}(\mathrm{L})$ 's, and $\zeta$ contain technology parameters.

Third, at time $t$, one can consider the long-run values defining $\mathrm{k}^{*}{ }_{\mathrm{t}}$ in (B-1) as expected values based on current information. We assume that these expectations are determined by the following univariate autoregressions specified as first differences,

$$
\begin{aligned}
& \Delta \mathrm{uc}^{*}{ }_{\mathrm{t}}=\mathrm{d}_{\mathrm{uc}}(\mathrm{L}) \Delta \mathrm{uc}_{\mathrm{t}}, \\
& \Delta \mathrm{s}_{\mathrm{t}}=\mathrm{d}_{\mathrm{s}}(\mathrm{L}) \Delta \mathrm{s}_{\mathrm{t}},
\end{aligned}
$$

where the $d_{u c}(L)$ 's and $d_{s}(L)$ 's are expectation parameters whose lag lengths need not be equal. Consequently, (B-5) provides a good reason why the length of the 
distributed lag for user cost and sales variables in our investment equation may not be equal. A disadvantage of (B-5) is that it uses a narrow information set, a point to which we return below.

Combining (B-1)-(B-5) and appending an error term $\left(\mathrm{e}_{\mathrm{t}}\right)$, we obtain the following investment equation,

$$
\begin{aligned}
& \mathrm{I}_{\mathrm{t}} / \mathrm{K}_{\mathrm{t}-1}=\zeta+\sigma \mathrm{b}(\mathrm{L}) \mathrm{d}_{\mathrm{uc}}(\mathrm{L}) \Delta \mathrm{uc}_{\mathrm{t}}+\xi \mathrm{b}(\mathrm{L}) \mathrm{d}_{\mathrm{s}}(\mathrm{L}) \Delta \mathrm{s}_{\mathrm{t}}+\mathrm{c}(\mathrm{L}) \underset{\mathrm{t}-1 / \mathrm{K}_{\mathrm{t}-2}+\mathrm{e}_{\mathrm{t}},}{(\mathrm{B}-6 \mathrm{a})} \\
& \mathrm{I}_{\mathrm{t}} / \mathrm{K}_{\mathrm{t}-1}=\zeta+\mathrm{f}_{\mathrm{uc}}(\mathrm{L}) \Delta \mathrm{uc}_{\mathrm{t}}+\mathrm{f}_{\mathrm{s}}(\mathrm{L}) \Delta \mathrm{s}_{\mathrm{t}}+\mathrm{f}_{\mathrm{I} / \mathrm{K}}(\mathrm{L}) \mathrm{I}_{\mathrm{t}-1 / \mathrm{K}_{\mathrm{t}-2}}+\mathrm{e}_{\mathrm{t}}, \quad(\mathrm{B}-6 \mathrm{~b})
\end{aligned}
$$

where $f_{u c}(L)=\sigma b(L) d_{u c}(L), f_{s}(L)=\xi b(L) d_{s}(L)$, and $f_{I / K}(L)=c(L)$. The $f(L)$ 's represent estimated coefficients, and are a mixture of technology and expectation parameters.

The long-run impacts of changes in the user cost and sales are assessed with the following transformed set of coefficients,

$$
\begin{aligned}
& \eta_{\mathrm{uc}}=\mathrm{f}_{\mathrm{uc}}(1) /\left(1-\mathrm{f}_{\mathrm{I} / \mathrm{K}}(1)\right), \\
& \eta_{\mathrm{s}}=\mathrm{f}_{\mathrm{s}}(1) /\left(1-\mathrm{f}_{\mathrm{I} / \mathrm{K}}(1)\right) .
\end{aligned}
$$

These long-run elasticities can have a structural interpretation in terms of the technology parameters -- $\sigma$ and $\xi--$ if we impose the following restrictions,

$$
\begin{aligned}
& \mathrm{b}(1) /(1-\mathrm{c}(1))=1, \\
& \mathrm{~d}_{\mathrm{uc}}(1)=1, \\
& \mathrm{~d}_{\mathrm{s}}(1)=1 .
\end{aligned}
$$

Equation (B-8a) implies that all orders for capital goods are ultimately delivered. Equations (B-8b) and (B-8c) imply that expected values ultimately move one-forone with changes in actual values in the information set. Note that the validity of the $\eta$ 's as long-run elasticities is not dependent on the validity of these assumptions used to identify the structural parameters. However, if we wish to separate technology and expectation parameters and thus, in principle, conduct policy experiments that adhere to the strictures of the Lucas Critique, such identification is essential. The quantitative importance of the Lucas Critique and hence the need to achieve identification has been questioned. See Section III for further discussion. 
The information set used to form expectations of $\Delta \mathrm{uc}^{*}{ }_{\mathrm{t}}$ and $\Delta \mathrm{s}^{*}{ }_{\mathrm{t}}$ can be expanded to include additional variables $\left(\mathrm{z}_{\mathrm{t}}\right.$ 's), and (B-5) is can be generalized as follows,

$$
\begin{aligned}
& \Delta \mathrm{uc}_{\mathrm{t}}=\mathrm{d}_{\mathrm{uc}, \mathrm{uc}}(\mathrm{L}) \Delta \mathrm{uc}_{\mathrm{t}}+\mathrm{d}_{\mathrm{uc}, \mathrm{z}}(\mathrm{L}) \mathrm{z}_{\mathrm{t}}, \\
& \Delta \mathrm{s}_{\mathrm{t}}=\mathrm{d}_{\mathrm{s}, \mathrm{s}}(\mathrm{L}) \Delta \mathrm{s}_{\mathrm{t}}+\mathrm{d}_{\mathrm{s}, \mathrm{z}}(\mathrm{L}) \mathrm{z}_{\mathrm{t}} .
\end{aligned}
$$

If the z's are variables already appearing as arguments in the investment equation (i.e., $\Delta \mathrm{uc}_{\mathrm{t}}, \Delta \mathrm{s}_{\mathrm{t}}$, and $\mathrm{I}_{\mathrm{t}} / \mathrm{K}_{\mathrm{t}-1}$ ), then the estimating equation is not altered,

$$
\begin{aligned}
\mathrm{I}_{\mathrm{t}} / \mathrm{K}_{\mathrm{t}-1}=\zeta & +\left\{\sigma \mathrm{b}(\mathrm{L}) \mathrm{d}_{\mathrm{uc}, \mathrm{uc}}(\mathrm{L})+\xi \mathrm{b}(\mathrm{L}) \mathrm{d}_{\mathrm{s}, \mathrm{uc}}(\mathrm{L})\right\} \Delta \mathrm{uc}_{\mathrm{t}} \\
& +\left\{\xi \mathrm{b}(\mathrm{L}) \mathrm{d}_{\mathrm{s}, \mathrm{s}}(\mathrm{L})+\sigma \mathrm{b}(\mathrm{L}) \mathrm{d}_{\mathrm{uc}, \mathrm{s}}(\mathrm{L})\right\} \Delta \mathrm{s}_{\mathrm{t}} \\
& +\left\{\mathrm{c}(\mathrm{L})+\sigma \mathrm{b}(\mathrm{L}) \mathrm{d}_{\mathrm{uc}, \mathrm{I} / \mathrm{K}}(\mathrm{L})+\xi \mathrm{b}(\mathrm{L}) \mathrm{d}_{\mathrm{s}, \mathrm{I} / \mathrm{K}}(\mathrm{L})\right\} \mathrm{I}_{\mathrm{t}-1} / \mathrm{K}_{\mathrm{t}-2}+\mathrm{e}_{\mathrm{t}}, \\
\mathrm{I}_{\mathrm{t}} / \mathrm{K}_{\mathrm{t}-1}=\zeta & +\alpha(\mathrm{L}) \Delta \mathrm{uc}_{\mathrm{t}}+\beta(\mathrm{L}) \Delta \mathrm{s}_{\mathrm{t}}+\lambda(\mathrm{L}) \mathrm{I}_{\mathrm{t}-1} / \mathrm{K}_{\mathrm{t}-2}+\mathrm{e}_{\mathrm{t}},
\end{aligned}
$$

where the $\alpha(\mathrm{L})$ 's, $\beta(\mathrm{L})$ 's, and $\lambda(\mathrm{L})$ 's are defined by the terms in braces in (A-6a'). In this case with more a more general information set, identification of the $\sigma$ and $\xi$ technology parameters becomes more difficult.

The estimating equation recognizes the possibility that cash flow may also enter as an argument to capture short-term credit constraints (i.e., entering (B-4)) and/or as an element of the information set used to form expectations of $\Delta u_{t}$ and $\Delta s_{t}$ (i.e., as another $\mathrm{z}$ entering (B-5)). In either case, current and lagged values of cash flow (scaled by the lagged capital stock) enters as additional regressors. Defining the cash flow coefficients as $\gamma(\mathrm{L})$, we obtain the following equation that is the basis for all of the estimates presented in this paper,

$$
\begin{aligned}
\mathrm{I}_{\mathrm{t}} / \mathrm{K}_{\mathrm{t}-1}=\zeta & +\alpha(\mathrm{L}) \Delta \mathrm{uc}_{\mathrm{t}}+\beta(\mathrm{L}) \Delta \mathrm{s}_{\mathrm{t}}+\gamma(\mathrm{L}) \mathrm{CF}_{\mathrm{t}} / \mathrm{K}_{\mathrm{t}-1} \\
& +\lambda(\mathrm{L}) \mathrm{I}_{\mathrm{t}-1} / \mathrm{K}_{\mathrm{t}-2}+\mathrm{e}_{\mathrm{t} .} .
\end{aligned}
$$

The long-run impacts of user cost, sales, and cash flow are defined as follow,

$$
\begin{aligned}
& \eta_{\text {uc }}=\alpha(1) /(1-\lambda(1)), \\
& \eta_{\mathrm{s}}=\beta(1) /(1-\lambda(1)),
\end{aligned}
$$




$$
\eta_{\mathrm{cf}}=\gamma(1) /(1-\lambda(1)),
$$

where $\eta_{\mathrm{uc}}$ and $\eta_{\mathrm{s}}$ are elasticities and $\eta_{\mathrm{cf}}$ is a semi-elasticity. The only differences between equation (B-7) and equation (2) in the text is the inclusion of time-specific $\left(\tau_{t}\right)$ effects and firm-specific subscripts on $\zeta$ and the variables. 


\section{CESifo Working Paper Series}

(for full list see www.cesifo.de)

772 Seppo Honkapohja and Kaushik Mitra, Learning Stability in Economies with Heterogenous Agents, September 2002

773 David Laidler, Inflation Targets Versus International Monetary Integration - A Canadian Perspective, September 2002

774 Morten I. Lau, Panu Poutvaara, and Andreas Wagener, The Dynamic Cost of the Draft, September 2002

775 Steven Brakman, Harry Garretsen, and Charles van Marrewijk, Locational Competition and Agglomeration: The Role of Government Spending, September 2002

776 Anke S. Kessler and Christoph Lülfesmann, The Theory of Human Capital Revisited: On the Interaction of General and Specific Investments, September 2002

777 Kjell Erik Lommerud, Frode Meland and Lars Sørgard, Unionized Oligopoly, Trade Liberalization and Location Choice, September 2002

778 Antonio Merlo and François Ortalo-Magné, Bargaining over Residential Real Estate: Evidence from England, September 2002

$779 \mathrm{Yu}-\mathrm{Fu}$ Chen and Michael Funke, Exchange Rate Uncertainty and Labour Market Adjustment under Fixed and Flexible Exchange Rates, September 2002

780 Michael S. Michael, International Migration, Income Taxes and Transfers: A Welfare Analysis, September 2002

781 Clemens Fuest and Alfons Weichenrieder, Tax Competition and Profit Shifting: On the Relationship between Personal and Corporate Tax Rates, October 2002

782 Jan Bouckaert and Hans Degryse, Softening Competition by Enhancing Entry: An Example from the Banking Industry, October 2002

783 Johann K. Brunner and Susanne Pech, Adverse Selection in the Annuity Market with Sequential and Simultaneous Insurance Demand, October 2002

784 Gregory D. Hess and Eduard Pelz, The Economic Welfare Cost of Conflict: An Empirical Assessment, October 2002

785 Jan Erik Askildsen, Uwe Jirjahn, and Stephen C. Smith, Works Councils and Environmental Investment: Theory and Evidence from German Panel Data, October 2002

786 Geir H. Bjønnes, Dagfinn Rime, and Haakon O. Aa. Solheim, Volume and Volatility in the FX-Market: Does it matter who you are?, October 2002 
787 John Evans and John Fingleton, Entry Regulation and the Influence of an Incumbent Special Interest Group, October 2002

788 Wolfgang Ochel, International Comparisons and Transfer of Labour Market Institutions, October 2002

789 B. Gabriela Mundaca, Moral Hazard Effects of Bailing out under Asymmetric Information, October 2002

790 Gene M. Grossman and Edwin L.-C. Lai, International Protection of Intellectual Property, October 2002

791 John Hassler, José V. Rodriguez Mora, Kjetil Storesletten, and Fabrizio Zilibotti, A Positive Theory of Geographic Mobility and Social Insurance, October 2002

792 Paul De Grauwe and Marianna Grimaldi, The Exchange Rate in a Model with Heterogeneous Agents and Transactions Costs, October 2002

793 Guido Friebel and Mariassunta Giannetti, Fighting for Talent: Risk-shifting, Corporate Volatility, and Organizational Change, October 2002

794 Jan Erik Askildsen, Badi H. Baltagi, and Tor Helge Holmås, Will Increased Wages Reduce Shortage of Nurses? A Panel Data Analysis of Nurses' Labour Supply, October 2002

795 Marko Köthenbürger and Panu Poutvaara, Social Security Reform and Intergenerational Trade: Is there Scope for a Pareto-Improvement?, October 2002

796 Paul De Grauwe and Laura Rinaldi, A Model of the Card Payment System and the Interchange Fee, October 2002

797 Volker Böhm and Tomoo Kikuchi, Dynamics of Endogenous Business Cycles and Exchange Rate Volatility, October 2002

798 Mariam Camarero, Javier Ordóñez, and Cecilio Tamarit, The Euro-Dollar Exchange Rate: Is it Fundamental?, October 2002

799 Misa Tanaka, How Do Bank Capital and Capital Adequacy Regulation Affect the Monetary Transmission Mechanism?, October 2002

800 Jörg Baten and Andrea Wagner, Autarchy, Market Disintegration, and Health: The Mortality and Nutritional Crisis in Nazi Germany, 1933-1937, October 2002

801 Saku Aura, Uncommitted Couples: Some Efficiency and Policy Implications of Marital Bargaining, October 2002

802 Wolfram F. Richter, Delaying Integration of Immigrant Labor for the Purpose of Taxation, October 2002

803 Gil S. Epstein and Shmuel Nitzan, The Politics of Randomness, October 2002 
804 John Hassler and José V. Rodriguez Mora, Should UI Benefits Really Fall over Time?, October 2002

805 Friedrich Breyer and Stefan Felder, The Dead-anyway Effect Revis(it)ed, October 2002

806 Assar Lindbeck and Solveig Wikström, E-exchange and the Boundary between Households and Organizations, November 2002

807 Dieter Bös, Contests Among Bureaucrats, November 2002

808 Steven Brakman, Harry Garretsen, and Marc Schramm, The Strategic Bombing of German Cities during World War II and its Impact on City Growth, November 2002

809 Florian Englmaier and Achim Wambach, Contracts and Inequity Aversion, November 2002

810 Sarbajit Sengupta, Delegating Recruitment under Asymmetric Information, December 2002

811 Rajshri Jayaraman, On the Partial Public Provision of a Private Good, December 2002

812 Stéphanie Stolz, Banking Supervision in Integrated Financial Markets: Implications for the EU, December 2002

813 Christian Keuschnigg, Taxation of a Venture Capitalist with a Portfolio of Firms, December 2002

814 Inés Macho-Stadler and David Pérez-Castrillo, Settlement in Tax Evasion Prosecution, December 2002

815 Rainer Niemann and Dirk Simons, Costs, Benefits, and Tax-induced Distortions of Stock Option Plans, December 2002

816 Jan-Egbert Sturm and Barry Williams, Deregulation, Entry of Foreign Banks and Bank Efficiency in Australia, December 2002

817 V. Anton Muscatelli, Patrizio Tirelli, and Carmine Trecroci, Monetary and Fiscal Policy Interactions over the Cycle: Some Empirical Evidence, December 2002

818 Claude Hillinger, A General Theory of Price and Quantity Aggregation and Welfare Measurement, December 2002

819 Erkki Koskela and Ronnie Schöb, Optimal Capital Taxation in Economies with Unionised and Competitive Labour Markets, December 2002

820 Sheilagh Ogilvie, Guilds, Efficiency, and Social Capital: Evidence from German ProtoIndustry, December 2002

821 Hans Gersbach and Verena Liessem, Financing Democracy, December 2002 
822 Costas Hadjiyiannis, Panos Hatzipanayotou, and Michael S. Michael, Optimal Tax Policies with Private-Public Clean-Up, Cross-Border Pollution and Capital Mobility, December 2002

823 François Ortalo-Magné and Sven Rady, Homeownership: Low Household Mobility, Volatile Housing Prices, High Income Dispersion, December 2002

824 Syed M. Ahsan and Panagiotis Tsigaris, Measuring the Social Discount Rate under Uncertainty: A Methodology and Application, December 2002

825 Kai A. Konrad, Altruism and Envy in Contests: An Evolutionarily Stable Symbiosis, December 2002

826 Robert S. Chirinko and Huntley Schaller, A Revealed Preference Approach to Understanding Corporate Governance Problems: Evidence from Canada, December 2002

827 Geir B. Asheim, Green National Accounting for Welfare and Sustainability: A Taxonomy of Assumptions and Results, December 2002

828 Andrea Gebauer, Chang Woon Nam, and Rüdiger Parsche, Lessons of the 1999 Abolition of Intra-EU Duty Free Sales for Eastern European EU Candidates, December 2002

829 Giacomo Corneo, Work and Television, December 2002

830 Vivek H. Dehejia and Yiagadeesen Samy, Trade and Labour Standards - Theory, New Empirical Evidence, and Policy Implications, December 2002

831 Geir B. Asheim and Wolfgang Buchholz, A General Approach to Welfare Measurement through National Income Accounting, December 2002

832 Aaron Tornell and Frank Westermann, The Credit Channel in Middle Income Countries, January 2003

833 Gebhard Flaig, Time Series Properties of the German Monthly Production Index, January 2003

834 Campbell Leith and Jim Malley, Estimated Open Economy New Keynesian Phillips Curves for the G7, January 2003

835 Burkhard Heer and Bernd Süssmuth, Inflation and Wealth Distribution, January 2003

836 Erkki Koskela and Leopold von Thadden, Optimal Factor Taxation under Wage Bargaining - A Dynamic Perspective, January 2003

837 Carola Grün and Stephan Klasen, Growth, Income Distribution, and Well-Being: Comparisons across Space and Time, January 2003

838 Robert S. Chirinko and Ulf von Kalckreuth, On the German Monetary Transmission Mechanism: Interest Rate and Credit Channels for Investment Spending, January 2003 